NBER WORKING PAPER SERIES

\title{
GIVE CREDIT WHERE CREDIT IS DUE: TRACING VALUE ADDED IN GLOBAL PRODUCTION CHAINS
}

\author{
Robert Koopman \\ William Powers \\ Zhi Wang \\ Shang-Jin Wei \\ Working Paper 16426 \\ http://www.nber.org/papers/w16426 \\ NATIONAL BUREAU OF ECONOMIC RESEARCH \\ 1050 Massachusetts Avenue \\ Cambridge, MA 02138 \\ September 2010
}

The views in the paper are solely those of the authors and may not reflect the views of the USITC, its Commissioners, or of any other organization that the authors are affiliated with. The authors thank participants of OECD-World Bank workshop "New metrics for global value chain analysis" in Paris, IEFS China 2010 Conference in Beijing, and seminar at Purdue University for helpful comments and suggestions. The authors are particularly grateful for the constructive discussion with Dr. Kei-Mu Yi at the Federal Reserve Bank of Philadelphia in developing the two-country cases and the relationship between our new measures of vertical specialization and the original HIY measures. The views expressed herein are those of the authors and do not necessarily reflect the views of the National Bureau of Economic Research.

NBER working papers are circulated for discussion and comment purposes. They have not been peerreviewed or been subject to the review by the NBER Board of Directors that accompanies official NBER publications.

(c) 2010 by Robert Koopman, William Powers, Zhi Wang, and Shang-Jin Wei. All rights reserved. Short sections of text, not to exceed two paragraphs, may be quoted without explicit permission provided that full credit, including $(\mathcal{O}$ notice, is given to the source. 
Give Credit Where Credit Is Due: Tracing Value Added in Global Production Chains

Robert Koopman, William Powers, Zhi Wang, and Shang-Jin Wei

NBER Working Paper No. 16426

September 2010, Revised September 2011

JEL No. F1,F2

\begin{tabular}{|c|c|}
\hline \\
\hline \multicolumn{2}{|c|}{$\begin{array}{l}\text { ABSTRACT } \\
\text { This paper provides both a conceptual framework for decomposing a country's gross exports int } \\
\text { components by source and a new bilateral database on value-added trade. Our parsimoniol } \\
\text { integrates all previous measures of vertical specialization and value-added trade in the } \\
\text { illustrate the potential of the decomposition, we present a number of applications including } \\
\text { revealed comparative advantages and constructing an index to describe whether a cour } \\
\text { likely in the upstream or downstream of global production chains. }\end{array}$} \\
\hline $\begin{array}{l}\text { Robert Koopman } \\
\text { Research Division } \\
\text { Office of Economics } \\
\text { US International Trade Commission } \\
500 \text { E Street SW } \\
\text { Washington, DC } 20436 \\
\text { Robert.Koopman@usitc.gov }\end{array}$ & $\begin{array}{l}\text { Zhi Wang } \\
\text { Research Division } \\
\text { Office of Economics } \\
\text { US International Trade Commissior } \\
500 \text { E Street SW } \\
\text { Washington, DC } 20436 \\
\text { zhi.wang@usitc.gov }\end{array}$ \\
\hline $\begin{array}{l}\text { William Powers } \\
\text { Research Division } \\
\text { Office of Economics } \\
\text { US International Trade Commission } \\
500 \text { E Street SW } \\
\text { Washington, DC } 20436 \\
\text { william.powers@usitc.gov }\end{array}$ & $\begin{array}{l}\text { Shang-Jin Wei } \\
\text { Graduate School of Business } \\
\text { Columbia University } \\
\text { Uris Hall 619 } \\
3022 \text { Broadway } \\
\text { New York, NY 10027-6902 } \\
\text { and NBER } \\
\text { shangjin.wei@columbia.edu }\end{array}$ \\
\hline
\end{tabular}




\section{Introduction}

As different stages of production are now regularly performed in different countries, intermediate inputs cross borders multiple times. As a result, traditional statistics on trade values become increasingly less reliable as a gauge of value contributed by any particular country. This paper integrates and generalizes the many attempts in the literature at tracing value added by country in international trade. We provide a conceptual framework that is more comprehensive than other measures in the literature. By design, this is an accounting exercise, and does not directly examine the causes and the consequences of global production chains. However, an accurate accounting of value added by source country is a necessary step toward a better understanding of all these issues.

Supply chains can be described as a system of value-added sources and destinations within a globally integrated production network. Within a supply chain, each producer purchases inputs and then adds value, which is included in the cost of the next stage of production. At each stage in the process, as goods cross an international border, the value-added trade flow is equal to the value added paid to the factors of production in the exporting country. However, as all official trade statistics are measured in gross terms, which include both intermediate inputs and final products, they "double count" the value of intermediate goods that cross international borders more than once. The conceptual and empirical shortcomings of gross trade statistics, as well as their inconsistency with the System of National Accounts (SNA) accounting standards, have been well recognized by the economics profession. ${ }^{1}$ The framework developed in this paper provides a complete decomposition of gross exports into its value-added components, thus making it possible to connect trade statistics with SNA standards.

Case studies of global value chains in industries such as electronics, apparel, and motor vehicles have provided detailed examples of the discrepancy between gross and value-added trade. According to a commonly cited study of the Apple iPod (Dedrick, Kraemer, and Linden, 2008), while the Chinese factory gate price of an assembled iPod is $\$ 144$, only $\$ 4$ constitutes Chinese value added. Other case studies of specific products show similar discrepancies. Case studies, while useful, do not offer a comprehensive description of an economy's participation in cross-border production chains. Several researchers have examined the issue of vertical specialization on a systematic basis, including the pioneering effort of Hummels, Ishii, and Yi

\footnotetext{
${ }^{1}$ See, for example, Leamer et al. (2006) and Grossman and Rossi-Hasberg (2008).
} 
(2001). Some measures, such as those proposed by HIY, turn out to be accurate only under special assumptions that do not hold in general. Others, to be reviewed in detail later, capture pieces of the value added embedded in a country's exports. This paper aims to provide the first unified framework that integrates the older literature on vertical specialization with the newer literature on value added trade. It completely decomposes gross exports and connects official gross statistics to value-added measures of trade. The framework distributes all value-added in a country's exports to its original sources, and it expresses individual sources and destinations of value added at either the country-wide or industry average level. Despite the breadth of the framework, it is also quite parsimonious, expressing major value-added sources in gross exports as the product of only three matrices.

Several previous papers have investigated source of value-added in Asian supply chains using the Asian input-output (AIO) tables produced by the Institute of Development Economies in Japan. Such papers include Koopman, Wang, and Wei (2009), Pula and Peltonen (2011), Wang, Powers, and Wei (2009), and WTO and IDE-JETRO (2011). However, these studies' reliance on the AIO tables precludes them from tracking value-added to and from countries outside of Asia, with the exception of flows to and from the United States.

Truly global analyses have become possible only recently, with the advent of global Inter-Country Input-Output (ICIO) tables based on the GTAP database. Such tables provide globally consistent bilateral trade flows, and allow comparison of production networks in different regions. Though usefully global in scope, the GTAP database does not separate imported intermediate and final goods in bilateral trade flows, so improvement has to be made ${ }^{2}$.

This paper is also related to Daudin, Rifflart, and Schweisguth (2010) and Johnson and Noguera (2010). They analyze global value-added trade flows using an estimated ICIO table based on the GTAP database, in which they proportionally allocate gross trade flows into intermediate and final goods and distributing across users. Each shows that countries and sectors differ widely in their ratio of value added to gross trade. This paper expands upon their analysis in the following five aspects:

\footnotetext{
${ }^{2}$ Efforts sponsored by European commission are underway to produce better and more up-to-date global ICIO tables, called the World Input-Output Database (WIOD), based on a compilation of single-country IO tables and detailed bilateral trade statistics for the years 1995-2006. Once the WIOD is completed, the framework in this paper can be applied to generate a time series decomposition of gross trade flows into their value added components.
} 
First, our unified and transparent framework incorporates all measures of vertical and value-added trade in the existing literature. For example, our framework decomposes a country's exports into five broad value added components. Both HIY's two original measures of vertical specialization and newer measures of value-added trade are components of our decomposition or their linear combinations. However, some measures have to be modified from their original definition in order to correctly specify sources of value added in a multi-country framework.

Second, by completely decomposing each country's gross exports into value-added components, we can establish a formal and precise relationship between value-added measures of trade and official trade statistics. We clearly show the similarities and differences between value-added trade measures and domestic content measures for the first time in the literature. Value-added trade is the value generated by one country but absorbed by another country, while the domestic content of exports depends only on where value is produced, not where and how that value is used.

Third, with the value added decomposition of gross exports, we can construct a quantitative index to assess whether a particular sector in a country is likely located in the upstream or downstream of the global production chain.

Fourth, our estimated global ICIO table better captures the international source and use of intermediate goods than in previous databases in two ways. By estimating intermediate goods in bilateral trade using the end-use classification (intermediate or final) of detailed import statistics, rather than the conventional proportionality approach that assumes the same split of imports between intermediate usage and final demands as in total absorption, we generate a global ICIO table that is better than the previous databases. ${ }^{3}$ In addition, we estimate separate input-output coefficients for processing trade in China and Mexico, the two major users of such regimes in the world. ${ }^{4}$ While other studies have used a similar correction for Chinese exports, the new Mexican IO table provides improved accuracy in estimates of NAFTA trade flows by distinguishing domestic and Maquiladora production.

\footnotetext{
${ }^{3}$ Feenstra and Jensen (2009) use a similar approach to separate final goods from intermediates in U.S. imports. They concord HS imports to end-use categories provided by the BEA. We concord HS imports to UN Broad Economic Categories, which are more applicable to international trade flows.

${ }^{4}$ Processing trade regimes can foster exports that have dramatically higher imported intermediate content than domestic use in some countries.
} 
Finally, we report a number of applications of our framework and database to illustrate their potential to reshape our understanding of global trade. For example, if one uses the official trade data to compute revealed comparative advantage, the business services sector is a comparative advantage sector for India. In contrast, if one uses value added in exports instead, the same sector becomes a revealed comparative disadvantage sector for India. As another example, the value added decomposition shows that a significant portion of China's trade surplus to the United States in gross trade terms reflects indirect value added exports that China does on behalf of Japan, Korea and Taiwan. While such stories have been understood in qualitative terms, our framework offers to a way to quantify these effects.

This paper is organized as follows. Section 2 presents the conceptual framework for decomposing gross trade into its value added components. Section 3 discusses computational issues. In particular, we show how the required inter-country IO model can be estimated from currently available data sources. Section 4 presents a number of applications that help to illustrate how the decomposition may alter our understanding of issues in international trade and in open-economy macroeconomics. Section 5 concludes.

\section{Decomposing Gross Trade into Value Added Components: Concepts and Measurement}

\subsection{Concepts}

With modern international production chains, value added originates in many locations. While detailing these sources and measuring their contribution to exports are important for a number of research and policy questions, existing measures are unsatisfactory. As noted, HIY provided the first empirical measures of participation in vertically specialized trade. However, their measure of foreign value in exports is valid only in a special case; they did not mathematically define their measure of indirect value-added exports through third countries; and these two measures do not capture all sources of value added in gross exports.

Two key assumptions are needed for the HIY's measure to accurately reflect foreign contents in exports. First, all imported intermediate inputs must contain 100\% foreign value added and no more than one country can export intermediates. In the HIY model, a country cannot import intermediate inputs, add value, and then export semi-finished good to another country to produce final goods. Nor can a country receive intermediate imports that embody its 
own value added, returned after processing abroad. Second, the intensity in the use of imported inputs is assumed to be the same whether goods are produced for export or for domestic final demand. This assumption is violated when processing exports raise the imported intermediate content of exports relative to domestic use, especially in China and Mexico. Therefore, HIY's measures do not hold generally with the multi-country, back-and-forth nature of current global production networks.

Section 2.2 illustrates how an ICIO model can allocate all the value added to each participating country using a block matrix formulation.This approach provides substantial clarity relative to other approaches in the literature, as we show below. To present the major concepts of our decomposition of gross exports by sources of value-added and show how they are related to or differ from earlier measuresin the literature, we start with a two-country case.

\subsection{Two-country case}

Assume a two-country (home and foreign) world, in which each country produces goods in $\mathrm{N}$ differentiated tradable sectors. Goods in each sector can be consumed directly or used as intermediate inputs, and each country exports both intermediate and final goods to the other.

All gross output produced by country $r$ must be used as an intermediate good or a final good at home or abroad, or

$$
X_{r}=A_{r r} X_{r}+A_{r s} X_{s}+Y_{r r}+Y_{r s}, \quad r, s=1,2
$$

Where $X_{r}$ is the $\mathrm{N} \times 1$ gross output vector of country $r, Y_{r s}$ is the $\mathrm{N} \times 1$ final demand vector that gives demand in country $s$ for final goods produced in $r$, and $A_{r s}$ is the $\mathrm{N} \times \mathrm{N}$ IO coefficient matrix, giving intermediate use in $s$ of goods produced in $r$. The two-country production and trade system can be written as an ICIO model in block matrix notation

$$
\left[\begin{array}{l}
X_{1} \\
X_{2}
\end{array}\right]=\left[\begin{array}{ll}
A_{11} & A_{12} \\
A_{21} & A_{22}
\end{array}\right]\left[\begin{array}{l}
X_{1} \\
X_{2}
\end{array}\right]+\left[\begin{array}{c}
Y_{11}+Y_{12} \\
Y_{21}+Y_{22}
\end{array}\right],
$$

and rearranging,

$$
\left[\begin{array}{l}
X_{1} \\
X_{2}
\end{array}\right]=\left[\begin{array}{cc}
I-A_{11} & -A_{12} \\
-A_{21} & I-A_{22}
\end{array}\right]^{-1}\left[\begin{array}{l}
Y_{11}+Y_{12} \\
Y_{21}+Y_{22}
\end{array}\right]=\left[\begin{array}{ll}
B_{11} & B_{12} \\
B_{21} & B_{22}
\end{array}\right]\left[\begin{array}{l}
Y_{1} \\
Y_{2}
\end{array}\right] .
$$

where $B_{s r}$ denotes the $\mathrm{N} \times \mathrm{N}$ block Leontief inverse matrix, which is the total requirement matrix that gives the amount of gross output in producing country $s$ required for a one-unit increase in 
final demand in country $r$. $Y_{r}$ is a $2 \mathrm{~N} \times 1$ vector that gives the global use of $r$ 's final goods. This system can be expressed succinctly as:

$X=(I-A)^{-1} Y=B Y$,

Where $X$ and $Y$ are $2 \mathrm{~N} \times 1$ vectors, and $A$ and $B$ are $2 \mathrm{~N} \times 2 \mathrm{~N}$ matrices.

Having defined the Leontief inverse matrix, we turn to measures of domestic and foreign contents, first for production, and then applied to trade. Let $V_{s}$ be the $1 \times \mathrm{N}$ direct value-added coefficient vector. Each element of $V_{s}$ gives the share of direct domestic value added in total output. This is equal to one minus the intermediate input share from all countries (including domestically produced intermediates):

$V_{r} \equiv u\left(I-\sum_{s} A_{s r}\right)$,

where $u$ is a $1 \times \mathrm{N}$ unity vector. To be consistent with the multiple-country discussion below, we also define $V$, the $2 \times 2 \mathrm{~N}$ matrix of direct domestic value added for both countries,

$V \equiv\left[\begin{array}{cc}V_{1} & 0 \\ 0 & V_{2}\end{array}\right]$.

While variations of this framework have been used in a number of recent studies, none uses the block matrix inverse as their mathematical tool and works out a complete tracing of all sources of value added. We turn to this task next.

Combining these direct value-added shares with the Leontief inverse matrices produces the $2 \times 2 \mathrm{~N}$ value-added share (VAS) matrix, our basic measure of value-added shares by source.

$$
\mathrm{VAS} \equiv V B=\left[\begin{array}{cc}
V_{1} B_{11} & V_{1} B_{12} \\
V_{2} B_{21} & V_{2} B_{22}
\end{array}\right] \text {. }
$$

Within VAS, each column of $V_{1} B_{11}$ denotes domestic value-added share of domestically produced products in a particular sector at home. Similarly, the columns of $V_{2} B_{21}$ denote the share of country 2's value-added in these same goods. Each of the first $\mathrm{N}$ columns in the VAS matrix includes all value added, domestic and foreign, needed to produce one additional unit of domestic products at home. The second $\mathrm{N}$ columns present value-added shares for production in country 2. Because all value added must be either domestic or foreign, the sum along each column is unity:

$$
V_{1} B_{11}+V_{2} B_{21}=V_{1} B_{12}+V_{2} B_{22}=u \text {. }
$$


The VAS matrix contains all the needed information to separate domestic and imported content shares in each country's production and trade at the sector level. Either final goods exports or total exports could be used as weights to calculate these shares when aggregation is needed. To compare with other measures of vertical specialization in the literature and to link our measures with official trade statistics, we use gross exports. ${ }^{5}$ Let $E_{r s}$ be the $\mathrm{N} \times 1$ vector of gross exports from $r$ to $s$. For consistency with the multi-country analysis below, we also define

$$
\begin{aligned}
& E_{r^{*}}=\sum_{s \neq r} E_{r s}=\sum_{s}\left(A_{r s} X_{s}+Y_{r s}\right), r, s=1,2 \\
& E=\left[\begin{array}{cc}
E_{1^{*}} & 0 \\
0 & E_{2^{*}}
\end{array}\right], \text { and } \\
& \hat{E}=\left[\begin{array}{cc}
\operatorname{diag}\left(E_{1^{*}}\right) & 0 \\
0 & \operatorname{diag}\left(E_{2^{*}}\right)
\end{array}\right],
\end{aligned}
$$

Where $E$ is a $2 \mathrm{~N} \times 2$ matrix and $\hat{E}$ is a $2 \mathrm{~N} \times 2 \mathrm{~N}$ diagonal matrix.

The combination of the value-added share matrix and an export matrix as weights produces a $2 \times 2 \mathrm{~N}$ matrix VAS_ $\hat{\mathrm{E}}$, our sectoral measure of value-added share by source country: VAS_ÊE $\equiv V B \hat{E}=\left[\begin{array}{cc}V_{1} B_{11} \hat{E}_{1} & V_{1} B_{12} \hat{E}_{2} \\ V_{2} B_{21} \hat{E}_{1} & V_{2} B_{22} \hat{E}_{2}\end{array}\right]$,

The elements of this matrix provide disaggregated value added by source in gross exports for each sector. It is important to note that this measure captures all upstream sectors' contributions to value added in a specific sector's exports. For example, in the electronics sector, VAS_ÊE includes value added in the electronics sector itself as well as value added in inputs from all other sectors (such as glass, rubber, transportation, and design) used to produce electronics for exports by the source country. Such an approach aligns well with case studies of supply chains of specific sectors and products, as in the iPod example cited earlier. As an alternative, one could measure the value added produced by the factors of production employed in a specific sector and then embodied in gross exports of all downstream sectors. This would include, for example, the value added by the electronics sector and then incorporated into gross

\footnotetext{
${ }^{5}$ The application to intermediates exports presents no problems here, because the content share in a product depends only on where it is produced. In other words, we maintain a basic assumption in the input-output literature that the value-added shares in intermediate goods are the same as in final goods within the same sector in each country.
} 
exports of computers, consumer appliances, and automobiles. This approach is closely related to the literature on factor contents of trade.

Domestic/foreign content of exports and value-added exports, while related, are different concepts. Although both concepts measure the value generated by factors employed in the producing country, domestic content of exports is independent of where that value is used. By contrast, value-added trade depends on how a country's exports are used by importers. It is the value-added generated by a country but absorbed by another country. Therefore, equation (12) defines related measures of domestic/foreign contents in sector level gross exports, not sector level value-added exports. Because the later depends on where the value-added is absorbed, it has to be defined in terms of final demand, as the following matrix after zeroing its diagonal:

$$
\hat{\mathrm{VAT}} \equiv \hat{V} B Y=\left[\begin{array}{cc}
\hat{V}_{1} & 0 \\
0 & \hat{V}_{2}
\end{array}\right]\left[\begin{array}{cc}
B_{11} & B_{12} \\
B_{21} & B_{22}
\end{array}\right]\left[\begin{array}{cc}
Y_{11} & Y_{12} \\
Y_{21} & Y_{22}
\end{array}\right]
$$

Where $Y_{\text {sr }}$ is an $\mathrm{N}$ by 1 vector and $Y$ is $2 \mathrm{~N}$ by 2 final demand matrix. $\hat{V}_{r}$ is a $\mathrm{N}$ by $\mathrm{N}$ diagonal matrix with direct value-added coefficients along the diagonal,has different dimension with $V$ matrix defined earlier. The resulting VÂT is a $2 \mathrm{~N}$ by 2 value-added production matrix, its diagonal elements give each country's production of value-added absorbed by itself while its off diagonal elements constitute the $2 \mathrm{~N}$ by 2 bilateral value-added trade matrix. Because the valueadded trade matrix is the off-diagonal elements of VÂT , it excludes value-added produced in the home country that returns home after processing abroad ${ }^{6}$.

To illustrate these two major concepts and their relations in the simplest possible terms, we will focus on the aggregate version throughout the rest of this section. The aggregate $(2 \times 2)$ measure of value-added by source in gross exports is given by VAS_E $\equiv V B E=\left[\begin{array}{cc}V_{1} B_{11} E_{1^{*}} & V_{1} B_{12} E_{2^{*}} \\ V_{2} B_{21} E_{1^{*}} & V_{2} B_{22} E_{2^{*}}\end{array}\right]$.

Although rather elementary with only two countries, VAS_E expresses the major concepts of our new value-added by source measure. Diagonal elements of VAS_E define the

\footnotetext{
${ }^{6}$ Due to production sharing between home and foreign countries, it is possible for value added exports to be zero between two countries with positive gross exports. For example, if country 1's exports to country 2 in car parts are all used as intermediaries in country's 2's car production that is entirely exported back to country 1 . Of course, the reverse is also possible - two countries could have zero gross exports but positive value added exports. For example, country 2 could record zero gross exports of steel to country 1 but have positive value added exports in steel if its car exports to country 1 embed domestically produced steel.
} 
domestic value-added in each country's exports. Off-diagonal elements give the foreign valueadded embodied in each country's exports.

In the two-country case, explicit solutions for the four $B_{r s}$ block matrices are not overly cumbersome, and allow us to demonstrate why HIY's vertical specialization measures are a special case of our new general measures. Applying the algebra of the partitioned matrix inverse, ${ }^{7}$ we have

$$
\left[\begin{array}{ll}
B_{11} & B_{12} \\
B_{21} & B_{22}
\end{array}\right]=\left[\begin{array}{cc}
\left(I-A_{11}-A_{12}\left(I-A_{22}\right)^{-1} A_{21}\right)^{-1} & B_{11} A_{12}\left(I-A_{22}\right)^{-1} \\
\left(I_{2}-A_{22}\right)^{-1} A_{21} B_{11} & \left(I-A_{22}-A_{21}\left(I-A_{11}\right)^{-1} A_{12}\right)^{-1}
\end{array}\right]
$$

Therefore, gross exports can be decomposed into foreign value-added (or VS, following the HIY notation) and domestic value-added (DV) as follows:

$$
\begin{aligned}
& \mathrm{DV}=\left[\begin{array}{c}
V_{1} B_{11} E_{1^{*}} \\
V_{2} B_{22} E_{2^{*}}
\end{array}\right]=\left[\begin{array}{l}
V_{1}\left(I-A_{11}-A_{12}\left(I-A_{22}\right)^{-1} A_{21}\right)^{-1} E_{1^{*}} \\
V_{2}\left(I-A_{22}-A_{21}\left(I-A_{11}\right)^{-1} A_{12}\right)^{-1} E_{2^{*}}
\end{array}\right] ; \\
& \mathrm{FV}=\left[\begin{array}{l}
V_{2} B_{21} E_{1^{*}} \\
V_{1} B_{12} E_{2^{*}}
\end{array}\right]=\left[\begin{array}{l}
u\left(A_{21}-A_{12}\left(I-A_{22}\right)^{-1} A_{21}\right)\left(I-A_{11}-A_{12}\left(I-A_{22}\right)^{-1} A_{21}\right)^{-1} E_{1^{*}} \\
u\left(A_{12}-A_{21}\left(I-A_{11}\right)^{-1} A_{12}\right)\left(I-A_{22}-A_{21}\left(I-A_{11}\right)^{-1} A_{12}\right)^{-1} E_{2^{*}}
\end{array}\right] .
\end{aligned}
$$

They are both $2 \times 1$ matrices.

Using the same notation, the HIY measure of foreign value added can be expressed as another $2 \times 1$ matrix:

$$
\mathrm{VS}=\left[\begin{array}{l}
u A_{21}\left(I-A_{11}\right)^{-1} E_{1^{*}} \\
u A_{12}\left(I-A_{22}\right)^{-1} E_{2^{*}}
\end{array}\right]
$$

Comparing equations (17) and (18), we can see that the HIY measure only captures foreign value added in gross exports when either $A_{12}=0$ or $A_{21}=0$; i.e., in the case when only one country's intermediate goods are used abroad. As Johnson and Noguera (2010) also point out, whenever both countries export intermediate products, the HIY measure diverges from the true measure of foreign value added in gross exports. Our new measure captures an important element omitted from the HIY's formula. For the home country, both domestic and foreign value added differ from their true values by the term $A_{12}\left(I-A_{22}\right)^{-1} A_{21} E_{21}$. Thus our new measure can account for a country importing its own value added which has been exported but return home after being processed abroad. In a more general context, VAS_E will properly attribute foreign and domestic contents to multiple countries when intermediate products cross borders in even

\footnotetext{
${ }^{7}$ See, for example, Simon and Blume $(1994,182)$.
} 
more complicated patterns. This will become clearer when we extend the measure to three or more countries.

The second HIY measure of vertical specialization (labeled as VS1 by HIY) details domestic value-added in inputs exported indirectly to third countries. Although an expression for such indirectly exported value-added (IV) has not been previously defined mathematically in the literature, it can be specified precisely in our framework. In a two-country world, the home country's IV is identical to foreign country's FV:

$$
\mathrm{IV}_{1}=V_{1} B_{12} E_{21} .
$$

This will not be true in the multi-country model that we turn to next. ${ }^{8}$

\subsection{Three or more countries}

The analysis can be generalized to any arbitrary number of countries. Production, valueadded shares, and sources of value-added in gross exports are given succinctly by:

$$
\begin{aligned}
& X=(I-A)^{-1} Y=B Y \\
& V A S=V B \\
& V A S_{-} E=V B E .
\end{aligned}
$$

With $\mathrm{G}$ countries and $\mathrm{N}$ sectors, $X$ and $Y$ are $\mathrm{GN} \times 1$ vectors; $A$ and $B$ are $\mathrm{GN} \times \mathrm{GN}$ matrices; $V$ and VAS are $\mathrm{G} \times \mathrm{GN}$ matrices; $\mathrm{E}$ is a $\mathrm{GN} \times \mathrm{G}$ matrix; and VAS_E is a $\mathrm{G} \times \mathrm{G}$ matrix. While we focus on the aggregate measures, all results continue to hold with full dimensionality and can be expressed simply by replacing the relevant weighting matrix.

In the multiple-country case, accurately calculating value added by source requires adjustments for intermediate inputs that cross multiple borders. Examining a three-country case in some details is useful for two reasons: (i) it exhibits nearly all the richness of the fully general multi-country analysis, and (ii) analytical solutions remain tractable and have intuitive explanations. For example, home's domestic block inverse matrix is given by ${ }^{9}$

$$
\begin{aligned}
B_{11} & =\left\{I-A_{11}-A_{12}\left[I-A_{22}-A_{23}\left(I-A_{33}\right)^{-1} A_{32}\right]^{-1}\left[A_{21}+A_{23}\left(I-A_{33}\right)^{-1} A_{31}\right] .\right. \\
& \left.-A_{13}\left[I-A_{33}-A_{32}\left(I-A_{22}\right)^{-1} A_{23}\right]^{-1}\left[A_{31}+A_{32}\left(I-A_{22}\right)^{-1} A_{21}\right]\right\}^{-1}
\end{aligned}
$$

\footnotetext{
${ }^{8}$ But, consistent with the many-country case, foreign value in direct exports will be measured along columns, while indirect value-added exports will be measured along rows.

${ }^{9}$ This expression is derived by iteratively applying the expression for the inverse of a partitioned matrix. (See appendix in Wang, Powers, and Wei (2009) for other analytical results.
} 
Comparing equation (21) with the equivalent term in equation (15), the three-country case contains more adjustments than the two-country case, all involving intermediate exports via third countries. Specifically, to measure domestic value-added share in country 1's total exports, the value-added embodied in its intermediate exports to country 2 and country 3 has to be accounted for. These intermediate goods could be used by the importing country (country 2 or country 3) to produce final goods and export back to the home country; or they could be used to produce intermediate goods exports to a third country (country 3 or country 2) that are then used to produce exports to the home country. Thus, adjustments have to be made for each of these intermediate flows. ${ }^{10}$ Similar adjustments are made to all measures of value-added by source to capture value added in production chains stretching across multiple borders.

As before, the value-added shares can be applied to gross exports to produce VAS_E. With three countries, VAS_E is a 3x3 matrix:

$V A S \_E=V B E=\left[\begin{array}{ccc}V_{1} B_{11} E_{1^{*}} & V_{1} B_{12} E_{2^{*}} & V_{1} B_{13} E_{3^{*}} \\ V_{2} B_{21} E_{1^{*}} & V_{2} B_{22} E_{2^{*}} & V_{2} B_{23} E_{3^{*}} \\ V_{3} B_{31} E_{1^{*}} & V_{3} B_{32} E_{2^{*}} & V_{3} B_{33} E_{3^{*}}\end{array}\right]$.

The distinction between value-added from direct and indirect sources in gross exports is much clearer with three countries than with two. The sum of off-diagonal elements along $a$ column is the true measure of value-added from foreign sources embodied in a particular country’s gross exports:

$$
\mathrm{FV}_{\mathrm{r}}=\sum_{s \neq r} V_{s} B_{s r} E_{r^{*}}
$$

The sum of off-diagonal elements along a row provides information on a country's value-added embodied as intermediate inputs in third countries' gross exports. This is the first explicit derivation of indirect value-added exports provided in the literature:

$$
\mathrm{IV}_{\mathrm{r}}=\sum_{s \neq t} V_{r} B_{r s} E_{s t}
$$

The diagonal terms measure domestic value added in gross exports:

\footnotetext{
${ }^{10}$ For example, $A_{23}\left(I-A_{33}\right)^{-1} A_{31}$ is the adjustment for country 2's exports of intermediate inputs to country 3 that are used to produce exports shipped to country 1 , while $A_{23}\left(I-A_{33}\right)^{-1} A_{32}$ is the adjustment for country 2's exports of intermediate inputs to country 3 that are used to produce exports shipped back to country 2 .

${ }^{11}$ Domestic value-added returned home, labeled as VS1* in Daudin et al (2010), can be separated from IV, as $\mathrm{VS}_{r}^{*}=V_{r} B_{r s} E_{s r}$.
} 
$\mathrm{DV}_{\mathrm{r}}=V_{r} B_{r r} E_{r^{*}}$.

Equation (8) shows that columns of the VAS matrix sum to unity, so the sum of domestic and foreign value added must account for all gross exports, ensuring that value-added from all sources sum to official trade flows and this relation is true at both aggregate and sector level:

$\mathrm{DV}_{r}+\mathrm{FV}_{r}=E_{r^{*}}$

\subsection{Extension to measures in the value-added trade literature}

Section 2.2 fully characterized value-added contributions from direct and indirect sources in a country' gross exports, formally generalizing the concept of vertical specialization to account for all sources of value-added in gross exports in a multi-country multi-sector framework. It also connects the vertical trade literature with value-added trade literature, generalizing concepts such as domestic value-added that returns home in goods and services after being processed or finished abroad, denoted VS1* by Daudinet al. (2010). This measure can be sizable for some large advanced economies.

To do this, we first divide gross exports into final demand and intermediates. Within intermediates, we further divide those goods that are consumed by the direct importer from those goods that are processed and exported by the direct importer for consumption or further processing in a third country:

$$
E_{r s}=Y_{r s}+A_{r s} X_{s}=\underbrace{Y_{r s}}_{\begin{array}{c}
\text { Finalgoods } \\
\text { exportedto } s
\end{array}}+\underbrace{A_{r s} X_{s s}}_{\begin{array}{c}
\text { Intermedides } \\
\text { absorbedin } s
\end{array}}+\underbrace{\sum_{t \neq r, s} A_{r s} X_{s t}}_{\begin{array}{c}
\text { Processedand exported } \\
\text { to third countries }
\end{array}}+\underbrace{A_{r s} X_{s r}}_{\begin{array}{c}
\text { Processedand } \\
\text { exportedback tor }
\end{array}},
$$

where $X_{\text {st }}$ is the output of country $s$ used to produce goods absorbed in country $t$. It is the product of the Leontief inverse matrix B and final demand matrix $\mathrm{Y}$ in equation (13). Note that the last three terms sum to the bilateral gross trade in intermediate goods, and all three terms may include both intermediates and final products produced in the importing country s.

Combining equations (25) and (27), and summing over all trading partners as in equation (9), and inserting into equation (26), we arrive at our key decomposition equation that states that a country's gross exports to the world is the sum of the following five broad terms: 


$$
\begin{aligned}
E_{r^{*}} & =\mathrm{DV}_{r}+\mathrm{FV}_{r} \\
& =\underbrace{V_{r} B_{r r} \sum_{s \neq r} Y_{r s}}+\underbrace{V_{r} B_{r r} \sum_{s \neq r} A_{r s} X_{s s}}+\underbrace{V_{r} B_{r r} \sum_{s \neq r} \sum_{t \neq r, s} A_{r s} X_{s t}}+\underbrace{V_{r} B_{r r} \sum_{s \neq r} A_{r s} X_{s r}}+\underbrace{\mathrm{FV}_{\mathrm{r}}} .
\end{aligned}
$$

(1)

(2)

(3)

(4)

(5)

(1) Domestic value-added embodied in exports of final goods and services absorbed by the direct importer;

(2) Domestic value-added embodied in exports of intermediate inputs used by the direct importer to produce its domestically needed products;

(3) Domestic value-added embodied in intermediate exports used by the direct importer to produce goods for third countries (“indirect value added exports')

(4) Domestic value-added embodied in intermediate exports used by the direct importer to produce goods shipped back to source ("reflected domestic value added”)

(5) Value-added from foreign countries embodied in gross exports ("foreign value added used in exports”).

The decomposition formula is also diagrammed in Figure 1. Equation (28) (or Figure 1) integrates the older literature on vertical specialization with the newer literature on value added trade, while ensuring that measured value-added from all sources accounts for total gross exports. The vertical specialization literature emphasized that gross exports contain two sources of value added, domestic and foreign. Equation (28) shows that a country's domestic valueadded could be further broken down into additional components that reveal the destination of a country's exported value added, including its own value-added that returns home in its imports. ${ }^{12}$

The sum of (1), (2), and (3) equals each country's value-added exports to the world; the sum of (1),(2),(3), and (4) equals domestic content in a country's gross exports, thus nicely connecting the two major concepts in the vertical specialization and value-added trade literature on the one hand, and clearly distinguishing them on the other hand.

In addition, all other measures in the literature can be derived from a combination of the five basic measures. For instance, the sum of (3) and (4) equals HIY's VS1 in gross exports;the sum of (1),(2), and (3) divided by gross exports equals Johnson and Noguera's ratio of value-

\footnotetext{
12 Since equation (27) decomposes all bilateral exports from country s to country r, it also simultaneously decomposes bilateral imports.
} 
added exports to gross exports (VAX ratio); and the sum of (4) and (5) equals the portion of trade that is “double counted"in official trade statistics. ${ }^{13}$

It is useful to note a caveat to the decomposition expressed in equation (28). In principle, imported intermediates (e.g., chemical) in one sector may be used to produce another intermediate (e.g., steel) that is used in the third sector at home (e.g., parts for chairs). That intermediate is then used to produce a product in the fourth sector that is eventually exported. In other words, the value added embedded in a given imported intermediate could travel through many sectors at home before it is exported. The expression in Equation (28) traces only the direct effect and the first round of the indirect effect. For this reason, it can be regarded as the firstorder approximation of the full order effect. The full order decomposition can be estimated by using information on domestic final demand in the importing country to obtain domestic value added embodied in the intermediate goods used by direct importers to produce domestically needed final goods. ${ }^{14}$

In any case, the first order decomposition has the nice property that the sum of the five items in Equation (28) equals 100\% of gross exports. This does not hold in general for the full order decomposition at the sector or bilateral level due to indirect value-added trade via intermediate goods. ${ }^{15}$ For the full-order decomposition, however, the five value-added components account for $100 \%$ of the country's gross exports only when trade values are summed over all sectors and all trading partners (to reach a country's total exports to the world). In this case, the only difference with the first order decomposition is the distribution across components (2), (3) and (4), with a decrease in value-added absorbed by the direct importer (2) and an equivalent increase of indirect value-added absorbed by other countries ((3) and (4)). The (fullorder) decomposition corresponding to Figure 1 using 2004 trade and production data is presented in Figure A1 in the online appendix.

\footnotetext{
${ }^{13}$ Component (3) should not be included in double counting, because when this value crosses a border for the second time, it becomes foreign value in the direct importer's exports. For this reason, it is not included as double counting to avoid an over-correction.

${ }^{14}$ This provides a modification of item (2) in equation (28); Modified versions of items (3) and (4) then could be computed according to equation (24).

${ }^{15}$ Because value-added trade could diverge from gross trade significantly at the sector and bilateral level, the share of indirect value-added exports (returning home or via third countries) could go to infinity when there is large indirect value-added exports but near zero gross exports
} 


\section{Data and results}

\subsection{The construction of an Inter-Country Input-output (ICIO) table and its data sources}

To implement the above decomposition, we need an inter-country input output table, that is, a database detailing international production and use for all flows of value added. The database should specify (a) transactions of intermediate products and final goods within and between each country at the industry level, (b) the direct value-added in production of each industry in all countries, and (c) the gross output of each industry in all countries. Such an ICIO table goes beyond a collection of single-country IO tables. It specifies the origin and destination of all transaction flows by industry as well as every intermediate and/or final use for all such flows. For example, an ICIO table would describe the number of electronics components produced in Japan that were shipped to China. It would also distinguish the number that were used as intermediate inputs in each Chinese sector and the number that were used in Chinese private household consumption and capital formation. However, these tables are not available on a global basis, and in fact are rarely available at the regional level. The available global databases, such as the GTAP Multi-Country Input-Output (MCIO) tables, do not have enough detail on the cross-border supply and use of goods to be directly used to implement our methodological framework.

To provide a workable dataset and empirically conduct our gross export decomposition, we construct a global ICIO table for 2004 based on version 7 of the GTAP database as well as detailed trade data from UN COMTRADE, and two additional IO tables for major emerging economies where processing exports are a large portion of their external trade. We integrate the GTAP database and the additional information with a quadratic mathematical programming model that (a) minimizes the deviation of the resulting new data set from the original GTAP data, (b) ensures that supply and use balance for each sector and every country, and (c) keeps all sectoral bilateral trade flows in the GTAP database constant. The new database covers 26 countries and 41 sectors and is used as the major data source of this paper. ${ }^{16}$ ICIO tables specify country $r$ 's use in sector $i$ of imports from sector $j$ from source country s. To estimate these detailed inter-industry and inter-country intermediate flows, we need to (i) distinguish intermediate and final use of imports from different sources in each sector, and (ii) allocate intermediate goods from a particular country source to each sector it is used within all

\footnotetext{
${ }^{16}$ See Appendix table A2 for countries included in each region and their concordance to GTAP regions.
} 
destination countries. We address the first task by concording detailed trade data to end-use categories (final and intermediate) using UN Broad Economic Categories (BEC), as described below. No additional information is available to properly allocate intermediates of a particular sector from a specific source country to its use industries at the destination economy, however. Thus, sector $j$ 's imported intermediate inputs of a particular product are initially allocated to each source country by assuming they are consistent with the aggregate source structure of that particular product. ${ }^{17}$

Although the GTAP database provides bilateral trade flows, it does not distinguish whether goods are used as intermediates or final goods. Our initial allocation of bilateral trade flows into intermediate and final uses is based on the UN BEC applied to detailed trade statistics at the 6-digit HS level from COMTRADE ${ }^{18}$. This differs from the approaches in Johnson and Noguera (2010) and Daudin, Rifflart, and Schweisguth (2010), which also transform the MCIO table in the GTAP database into an ICIO table. However, they do not use detailed trade data to identify intermediate goods in each bilateral trade flow. Instead, they apply a proportionality method directly to the GTAP trade data; i.e., they assume that the proportion of intermediate to final goods is the same for domestic supply and imported products.

The use of end-use categories to distinguish imports by use is becoming more widespread in the literature and avoids some noted deficiencies of the proportionality method. ${ }^{19}$ Feenstra and Jensen (2009) use a similar approach to separate final goods from intermediates in U.S. imports in their recent re-estimation of the Feenstra-Hanson measure of material offshoring. Dean, Fung, and Wang (2009) show that the proportionality assumption underestimates the share of imported goods used as intermediate inputs in China's processing trade. Nordas (2005) states that the large industrial countries have a higher share of intermediates in their exports than in their imports, while the opposite is true for large developing countries. These results imply that the

\footnotetext{
${ }^{17}$ For example, if $20 \%$ of U.S. imported intermediate steel comes from China, then we assume that each U.S. industry obtains $20 \%$ of its imported steel from China. Such an assumption ignores the heterogeneity of imported steel in different sectors. It is possible that $50 \%$ of the imported steel used by the U.S. construction industry may come from China, while only $5 \%$ of the imported steel used by auto makers may be Chinese.

${ }^{18}$ Both the zero/one and a weighting scheme can be used with BEC, We used a zero/one classification. Shares based on additional information could be applied to dual use products to further improve the allocation. These are areas for future research.

${ }^{19}$ The literature notes that the UN BEC classification has shortcomings of its own however, particularly its inability to properly identify dual-use products such as fuels, automobiles, and some food and agricultural products.
} 
intermediate content of imports differs systematically from the intermediate content in domestic supply.

The less distorted intermediate share estimates provides a better row total control for each block matrix of $A_{s r}$ in the ICIO coefficient matrix $A$, thus improving the accuracy of the most important parameters (the IO coefficients) in an ICIO model. However, it still does not properly allocate particular intermediate goods imported from a specific source country to each using industry (the coefficients in each cell of a particular row in each block matrix $A_{s r}$ still have to be estimated by proportionality assumption). This allocation is especially important to precisely estimate value-added by sources for a particular industry, although it is less critical for the country aggregates because total imports of intermediates from a particular source country are fixed by observed data, so misallocations will likely cancel out.

To provide an accurate comparison of the UN BEC method versus the proportionality approach, we would need true inter-country IO coefficients as a reference, which unfortunately do not exist on a global scale. The only available reference is an ICIO table for nine East-Asian countries and the United States constructed by the Institute of Development Economics in Japan in cooperation with National Statistical agencies in related countries based in part on a survey of firms. The allocation of imports between intermediates and final demand in the pre-release version of the 2005 Asian Input-Output (AIO) table provides a reference point for comparison with our results, although it may also be considered as just another more extensive estimate. In Table 1, for electronic machinery imports, we list the share of intermediate inputs in imports from 12 countries and the world by the United States and Japan in three ways: (a) what is assumed by the proportionality assumption, (b) what is implied by the BEC classification, both from our 2004 global ICIO table, and (c) what is reported in the 2005 AIO table.

The information on imports by the United States is listed in Columns 1-4. Under the proportionality assumption, the share of import across all exporting countries that are used as intermediates is a constant (54.2\%) as reported in Column 1. By definition, its correlation with the shares in the AIO column is zero. Under BEC, the share varies by source countries (Column 2). The correlation between the share under BEC and the share from AIO is 0.98.

Similarly, we list the shares that go into intermediates for Japan's imports of electronic machinery. Again, the correlation between the share under the proportionality assumption and the reference value is zero. In comparison, the correlation between the share under BEC and the 
reference value is 0.64. These examples illustrate possible improvement of using the BEC classification over the proportionality assumption ${ }^{20}$.

\subsection{Complete decomposition of gross exports}

Table 2 presents a complete decomposition of each country's gross exports to the world in 2004 using the five basic value-added components specified in equation (28). The column number in the first five columns corresponds to both the item number in Equation (28) and the box number in Figure 1.

Although these elements have been independently computed based on different elements in the VAS_E matrix and equation (28), they sum to exactly 100 percent of gross exports, thus verifying that the decomposition is complete. This is the first such decomposition in a global setting. It provides a more detailed break out of domestic value-added in exports than has been previously available in the literature and shows that there are large difference in value-added components across countries, indicating substantial differences in the role that countries play in global production networks.

For example, for the United States, the share of foreign value added in its exports is $12.9 \%$, indicating that most of its exports reflect its own domestic value added. In comparison, for China's processing exports, the share of foreign value added is 56.6\%, indicating China's domestic value added accounts for less than half the value of its processing exports. Appendix B provides additional detail on value-chain participation by different global regions.

The right-hand panel of table 2 presents related measures (or their properly-measured analogues) from the literature derived from the five basic value-added measures.To reiterate the connection of these five basic components to measures in the existing literature: column (7) reports the ratio of value-added exports to gross exports (VAX ratio) proposed by Johnson and Noguera (2010) by adding columns (1), (2), and (3); column (8) reports share of VS1 proposed by HIY by adding columns (3) and (4); column (9) lists the share of domestic contents extensively discussed in the vertical specialization literature by summing columns (1), (2), (3)

\footnotetext{
${ }^{20}$ Appendix Table A1 compares the average splits between intermediates and the final consumption between the two approaches in the aggregate.
} 
and (4); Column (11) gives the share of vertical trade by adding columns (5) ${ }^{21}$ and (8), which is an indicator of how intensively a country participant in global production chain.

Column (10) reports the percentage of multiple counting in official trade statistics by adding columns (4) and (5). At the global level, only domestic value added in exports absorbed abroad are value-added exports; value added embodied in imported intermediates are other country's domestic value-added, and so cannot count as additional value-added for the importing country. In addition to foreign value added in exports, domestic value-added that returns home from abroad is also a part of double counting in official trade statistics, since it crosses borders at least twice. Such reflected value added has to be separated from domestic value-added absorbed abroad in order to fully capture multiple counting in official trade statistics. Therefore, for any country's gross exports, the double counting portion equals the share of gross exports greater than the value-added exports between countries. It is the foreign value-added portion plus the portion of domestic value-added that returns home. This share is about $25.6 \%$ for total world exports in 2004 based on our ICIO database.

Similar decompositions can be performed at the country-sector level. In Table A5, we report the decomposition results for ten largest exporters (based on the value of gross exports) in each of the 19 manufacturing sectors in our database. The sector-level results are subject to the limitations discussed previously, since the inaccuracy of cross-country intermediate-use coefficients could introduce unknown noise into both the sources of value-added I gross exports and value-added trade estimates at the industry level.

\subsection{Position of countries within global value chains: Evidence from sector-level decompositions}

By using the decomposition results at the country-sector level, we can construct an index that helps us to gauge whether a country is likely to be in the upstream or downstream of the global value chain (GVC) in any particular sector. We can also construct a separate index that helps us to gauge the extent to which a country-sector is involved in the global production chain.

For an index to capture a country's position (i.e., upstream or downstream), it makes sense to compare that country's exports of intermediates in that sector that are used by other countries, with that country's use of imported intermediates in the same sector. If a country lies upstream in the global value-chain, it participates by producing inputs for others, either by

\footnotetext{
${ }^{21}$ Column (5) corresponds to the VS share in HIY(2001).
} 
providing raw materials (such as Russia), or by providing manufactured intermediates (such as Japan), or both. For such a country, its indirect value added exports (IV) share in gross exports will be higher than its FV share. In comparison, if a country lies downstream in the global value chain, it will use a large portion of other countries intermediates to produce final goods for exports, and its FV share will be higher than its IV share.

We define a country-sector level index for the position in the global value chain as the log ratio of a country-sector's supply of intermediates used in other countries' exports to the use of imported intermediates in its own production.

GVC_Position $_{i r}=\operatorname{Ln}\left(1+\frac{\mathrm{IV}_{\text {ir }}}{E_{i r}}\right)-\operatorname{Ln}\left(1+\frac{\mathrm{FV}_{\text {ir }}}{E_{i r}}\right)$

If the country-sector lies upstream in a supply chain, the numerator tends to be large. On the other hand, if it lies downstream, then the denominator tends to be large. For example, in the home electronics sector, if Japan specializes in providing components to assembly firms in China, the index tends to take on a high value for Japan and a low value for China.

Of course, two countries can have identical values of the GVC position index in a given sector while having very different degrees of participation in GVCs. Therefore, the position index has to be used in conjunction with another index that summarizes the importance of the global supply chain for that country-sector. We define a GVC participation index as

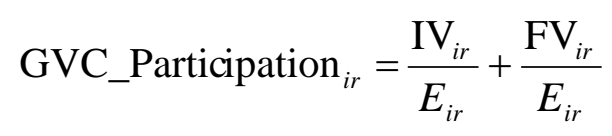

We compute these two indices for all countries and sectors. We organize the information by sectors and present some of them in Figure 2. For example, the upper left graph of Figure 2 describes the electronic equipment sector. Numbers in the parentheses are 2 digit ISIC codes. Japan, Mexico “normal” (i.e., non-processing exports), Western Europe (WEU) ${ }^{22}$ and the United States are the most upstream countries in the electronics value chain (given on the left axis), indicating that they are the main suppliers of components to firms in the same industry in other countries. In comparison, Singapore, China processing exports, new EU member countries

\footnotetext{
${ }^{22}$ The original 15 EU members are referred to here as "Western EU”, while the next 12 members to accede are referred to as "Eastern EU” or "new EU members".
} 
(EEU), Indonesia, and Thailand are at the most downstream end of the value chain, indicating that their exports mostly use imported components for production. To see why it is important to look at the participation index (right vertical axis) together with the position index (left vertical axis), we take another look at Japan and Mexico normal. While they both occupy upstream positions in the value chain, Japan has a high participation value, but Mexico normal has a relatively trivial value for the participation index. Being a part of global production chain is a far more important feature for the electronic equipment sector in Japan than for the same sector in Mexico normal.

In the upper right graph of Figure 2, we present the position and participation indexes for the finished metal products sector. While Mexico, Japan, the United States and Mexico normal are the most upstream based on the position index, participation in the GVC is only substantial for the United States and Japan accordingto the participation index. At the other extreme, China processing, Mexico processing, and Singapore ${ }^{23}$ have the most downstream locations. The participation index for them (all in excess of $70 \%$ ) indicates that assembly using primarily imported inputs is the main feature of their exports in this sector.

The graphs for other sectors can be read similarly, which we will not go into detail to save space. We would note a few broad patterns. First, the importance of separating processing and normal exports for China and Mexico is clear. While their processing exports tend to be heavy users of imported inputs, whereas their normal exports often supply intermediates to other countries' exports. Second, the original EU member countries and new accession countries also tend to lie on the two ends of the global production chain. For example, in electronic equipment, ferrous metal, and papers and publishing, Western EU countries tend to lie upstream, whereas Central and Eastern EU countries tend to be more downstream in the value chains.

We want to end this subsection with a note of caution in using sector-level decompositions. As we discussed earlier, the lack of information in our current database on how imported inputs are distributed among sector users within each country may introduce unknown noise into both sources of value-added in gross exports and value-added trade estimates at sector

\footnotetext{
${ }^{23}$ For Singapore, because the GTAP database does not take out transshipment trade and re-exports as it did for Hong Kong, the position index may exaggerate the extent to which Singapore is at the downstream of the production chain.
} 
level. If we focus on country rankings rather than the exact numerical numbers, the impact of the errors is likely to be smaller.

\section{Broad implications for a better understanding of global trade}

The decomposition results have implications for a variety of research and policy questions. In this section, to illustrate the potential importance of the decomposition, we brief discuss a few applications.

\subsection{Revealed Comparative Advantage index based on gross and value-added trade}

The concept of revealed comparative advantage (RCA for short), proposed by Balassa (1965), has proven to be useful in many research and policy applications. In standard applications, it is defined as the share of a sector in a country's total gross exports relative to the world average of the same sector in world exports. When the RCA exceeds one, the country is said to have a revealed comparative advantage in that sector; when the RCA is below one, the country is said to have a revealed comparative disadvantage in that sector. The problem of multiple counting of certain value added components in the official trade statistics suggests that the traditional computation of RCA could be noisy and misleading. Our value added decomposition of exports provides a way to remove the distortion of multiple counting by focusing on domestic value added in exports.

We re-compute the RCA index at the country-sector level for all the countries and sectors in our database. Due to space constraints, we select two sectors and compare the country rankings of RCAs using both gross exports and domestic value added in gross exports. In Figure 3 , we report the two sets of RCA indices for the finished metal products sector. Using gross exports data, both China and India show a strong revealed comparative advantage (ranked the first and fourth, respectively, among the set of countries in our database, and with the absolute values of RCA at 1.94 and 1.29, respectively). However, when looking at domestic value added in that sector's exports, both countries ranking in RCA drop precipitously to $7^{\text {th }}$ and $15^{\text {th }}$ place, respectively. ${ }^{24}$ In fact, for India, the sector has switched from being labeled as a comparative

\footnotetext{
${ }^{24}$ Sectoral value added here includes value produced by the factors of production employed in the finished metal products sector and then embodied in gross exports of all downstream sectors, rather than the value added employed in upstream sectors that are used to produce finished metal products in the exporting country. This distinction is particularly important in the business services sector, discussed next.
} 
advantage sector to a comparative disadvantage sector. Unsurprisingly, the ranking for some other countries moves up. For example, for the United States, not only its RCA ranking moves up from $10^{\text {th }}$ place under the conventional calculation to the $3^{\text {rd }}$ place under the new calculation, finished metal products industry also switches from being labeled as a comparative disadvantage sector to a comparative advantage sector.

Another example is the "real estate and business services" sector. Using data on gross exports, India exhibits a strong revealed comparative advantage in that sector on the strength of its unusually high share of business services exports in its overall exports. However, once we compute RCA using domestic value added in exports, the same sector becomes a comparative disadvantage sector for India! One key reason for the change is that business services in advanced countries are often exported indirectly by being embedded in these countries manufacturing exports. Indeed, the RCA rankings for this sector in the United States, the European Union and Japan all move up using data on the domestic value added in exports. Therefore, compared to the share of this sector in other countries' exports (after taking into account indirect value added exports), the Indian share of the sector in its exports becomes much less impressive.

These examples illustrate the possibility that our understanding of trade patterns and revealed comparative advantage could be modified substantially once we have the right data on domestic value added in exports.

\subsection{Magnification of trade costs from multi-stage production}

As noted by Yi (2003, 2010), multi-stage production magnifies the effects of trade costs on world trade. There are two separate magnification forces. The first exists because goods that cross national barriers multiple times incur tariffs and transportation costs multiple times. The second exists because tariffs are applied to gross imports, even though value added by the direct exporter may be only a fraction of this amount. Different participation in global networks affects the extent to which different countries are affected by such cost magnification. However, Yi (2003) does not actually measure the magnification of tariffs, though it is important to his simulations exercise.

Our value added estimates provide an ideal way to re-examine the magnification issue. In Table 3, we first report standard trade costs applied to exports of final goods in columns (1)-(3). 
These include the trade-weighted average transportation margin (ad valorem cif-fob margin), the trade-weighted tariff rate applied abroad (ad-valorem equivalent), and the total of these two trade costs. Column (4) reports the share of foreign value added in final manufacture goods exports, including domestic value that returns to the source country. ${ }^{25}$ These imported intermediate inputs are used to produce final manufacture goods exports, and so incur multiple tariffs and transportation costs. The foreign content shares are combined with tariff rates and transportation margins applicable to each country's own imports to calculate the trade costs that accompany use of imported intermediate inputs in producing exports.These trade costs (as a share of f.o.b. export value) are presented in columns (5)-(7). Specifically, these three columns report the tradeweighted average costs for intermediate inputs from the other 25 countries/regions in our database that are used in the exporting country to produce final manufacture goods exports.

The next three columns report our illustrative calculation of the first order magnification effect of using imported intermediate inputs to produce exports. Column (8) represents the magnification effect if transport costs were the only factor that augments the trading costs; Column (9) represents the magnification effect if tariffs were the only factor that augments the trading costs. Finally, Column (10) is the magnification effect when both transport costs and tariffs are taken into account. For instance, one additional stage of production increase trade costs in Vietnam's manufacturing sector by $91 \%$ of its standard cost.

Although the number is already quite high for a number of countries ${ }^{26}$, these values still represent only the lower bound of the true multi-stage trade costs, because these inputs may have already crossed multiple borders before reaching the final exporter.

Emerging Asia has some of the highest magnification ratios because their manufacturing industries are involved in longer supply chain, use more imported inputs, in some cases (such as Vietnam and Thailand) impose high tariffs on their intermediate imports. The effects of these barriers on the magnification ratio are tempered somewhat by the high standard trade cost these countries face on their exports because of longer distance transportation to final destination of their exports than other emerging economies. China is notable for having the lowest trade costs on imports in the region, and hence the lowest magnification factor in the region, since it applies very low tariffs on its imported intermediate to produce its exports (about half of its exports are

\footnotetext{
${ }^{25}$ In practice, each country's vector of foreign value shares for all products is used in the calculation.

${ }^{26}$ Table A6 in the online appendix reports descriptive statistics for the 16 manufacturing sectors included in table 3, such as the range and standard deviation of the sector-level results.
} 
processing trade with no tariff charged on intermediate imports). Relative to Asia, other emerging countries in our dataset typically involve shorter supply chains, use less imported inputs and apply lower tariffs to their own intermediate imports, and hence have lower ratios. ${ }^{27}$

Developed economies tend to have low magnification ratios due to two reasons. First, they apply relatively low tariffs to their intermediate imports. Second, the share of foreign value added in their exports tends to be low.

The second magnification force occurs because tariffs are applied to gross export value instead of the value added in the direct exporting country. Table 3 also reports the magnification ratio of the "effective" tariff rate to the standard tariff rate. Column (11) reports the effective tariff rate, which equals the standard tariff rate in column (2) plus the tariff applied by the producing country to its intermediate goods imports in column (6), divided by the domestic content share (which is 100 minus column (4)). Column (12) reports the implied magnification ratio due to the presence of vertical specialization. These effects are generally larger than the tariff magnification factor reported in column (9).

Generally speaking, tariffs play a greater role than transportation costs in the magnification of trade costs in the presence of GVCs for emerging market economies, while the opposite is true for most developed countries. The fact that the domestic value-added share in emerging economies' manufacturing exports is usually lower than that in developed countries tends to amplify the effective trade cost for developing countries. Reducing tariffs and nontariff barriers in manufacturing sectors globally is fully consistent with the interest of emerging market economies by lowering the cost for developing countries' participation in GVCs. Lowering “own” tariffs on intermediate inputs for domestic manufacturing production would significantly reduce the magnification effects as demonstrated in column (9), while lowering such tariffs in other countries would significantly reduce the effective rate of protection, as seen in columns (11) and (12), due to the lower domestic value-added share in most developing countries' manufacturing exports.

\footnotetext{
${ }^{27}$ Mexican processing exports is an unusual case. Although trade costs on imports are relatively low, the magnification ratio is quite high, because the standard trade costs are low (1.5\%) and the foreign content share in exports is substantial (63.5\%).
} 


\subsection{Bilateral trade imbalance}

Because a country's gross exports embeds value added from other countries, bilateral trade balance in value added terms can be very different from bilateral balance in gross trade terms. This point is already well understood qualitatively. The decomposition results in this paper allow us to quantify the difference.

Figure 4 provides a scatter plot of the trade balance in value added terms against the trade balance in standard trade statistics for all bilateral country pairs in our ICIO database. Without loss of generality, the two countries in any pair are always ordered in such a way that the trade balance in gross term is non-negative. A negative value-added to gross BOT ratio indicates there is a sign change between BOT measured in gross and value-added terms. All observations that lie below the 45 degree line have their bilateral trade imbalance smaller in value-added terms than that in gross terms, and vice visa for observations that lie above the 45 degree line.

Value-added flows give a much different picture of the contributions of China and Japan to the U.S. and Western EU countries' trade deficits. Because China is the final assembler in a large number of global supply chains, and it uses components from many other countries, especially East Asian countries, its trade surplus with US and Western EU countries measured in value-added term is $41 \%$ and $49 \%$ less than that measured in gross terms. In contrast, Japan's trade surplus with the U.S. and Western EU countries are $40 \%$ and $31 \%$ larger measured in value-added terms, because Japan exports parts and components to countries throughout Asia that are eventually assembled into final products and exported to the United States and Western $\mathrm{EU}$ countries. ${ }^{28}$ Zooming in near the origin shows that the trade balances of a number of country pairs even have opposite signs measured in value-added and gross terms. For example, Japan's trade balance vis-à-vis China is switched from a surplus in gross trade terms to a deficit in value added terms. This is consistent with the notion that a significant part of Japan's exports to China are components used by China-based firms for exports to the United States, the European Union and other markets. This further illustrates potentially misleading nature of gross bilateral trade imbalance.

\footnotetext{
${ }^{28}$ Figure 4 also shows that the Korea-China-U.S. triple trade relationship is similar to the Japan-China-U.S. one.
} 


\subsection{Other applications}

The set of examples discussed so far certainly does not exhaust the possible applications. For example, the Federal Reserve Board and the IMF routinely compute effective exchange rates using trade weights that are based on gross exports and imports. A conceptually better measure should weight trading partners based on the relative importance in value added trade rather than in gross trade terms. Our decomposition results make it feasible to do such computations.

As another example, for some research or policy questions, one might need to look at the response of a country's bilateral or multilateral trade to exchange rate changes. Once one recognizes that there is a potential mismatch between trade in value added and trade in gross terms, one would want to take this into account. Our decomposition allows for a correction.

\section{Conclusions}

We have developed a unified measure for sources of value-added in gross exports with a transparent conceptual framework based on the block-matrix structure of an inter-country IO model. This new framework incorporates all previous measures of vertical specialization and value-added trade in the literature while adjusting for the back-and-forth trade of intermediates across multiple borders. With a full concordance between value-added components and official gross trade statistics, it opens the possibility for the System of National Accounts (SNA) to accept the concept of value-added trade without dramatically changing current customs trade data collection practice. This may in turn provide a feasible way for international statistical agencies to report value-added trade statistics regularly in a relatively low cost fashion.

The contributions of this paper lie largely in its comprehensive framework, its approach to database development, and the new detailed decomposition of domestic value-added that has revealed about each country's role in global value chains at industry average level. To improve the sector level results, current end use classifications, such as the UN BEC, need to be extended to dual use products and services trade. In addition, methods need to be developed to properly distribute imports to domestic users either based on cross country statistical surveys of the domestic distribution of imports or based on firm level and Customs transaction-level trade data.

The creation of a database that encompasses detailed global trade in both gross and value-added terms, however, will allow us to move from a largely descriptive empirical exercise to analysis of the causes and consequences of differences in supply chain participation. We have 
discussed the use of the decomposition results to re-compute revealed comparative advantages and bilateral trade balance. Surely there are other applications that may affect our understanding of trade and other issues. We leave other applications to future research.

\section{References}

Balassa, Bela. 1965. “Trade Liberalization and 'Revealed' Comparative Advantage.” Manchester School of Economic and Social Studies, 33, 99-123.

Johnson, Robert, Rudolfs Bems, and Kei-Mu Yi. 2011. "'Vertical Linkages and the Collapse of Global Trade."American Economic Review, Papers and Proceedings,101:2, May.

Daudin, Guillaume, Christine Rifflart, and Danielle Schweisguth. 2010. "Who Produces for Whom in the World Economy?” OFCE Working Paper, Sciences Po Paris, July.

Dean, Judith, K.C. Fung, and Zhi Wang. 2011. "How Vertically Specialized is Chinese Trade?” Review of International Economics, Forthcoming.

Dedrick, Jason, Kenneth L. Kraemer, and Greg Linden. 2008. "Who Profits from Innovation in Global Value Chains? A Study of the iPod and notebook PCs." Paper presented at the Sloan Industry Studies Annual Conference, Boston, MA, May.

Feenstra, Robert and J. Bradford Jensen. 2009. "Evaluating Estimates of Materials Offshoring from U.S. Manufacturing." Paper presented at the National Academy of Public Administration conference "Measurement Issues Arising from the Growth of Globalization," November 6-7.

Grossman, G. and E. Rossi-Hansberg (2008). "Trading Tasks: A Simple Theory of Offshoring,” American Economic Review, 98:5, 1978-1997.

Hummels, D., J. Ishii, and K. Yi. 2001. "The Nature and Growth of Vertical Specialization in World Trade.” Journal of International Economics 54:75-96.

Johnson, Robert, and Guillermo Noguera. 2010. “Accounting for Intermediates: Production Sharing and Trade in Value-added," Paper presented at NBER ITI Program Meeting, Boston, $M A$. August.

Koopman, Robert, Zhi Wang, and Shang-Jin Wei. 2008. "How Much Chinese Exports Is Really Made in China-Assessing Foreign and Domestic Value-added in Gross Exports.” NBER Working Paper 14109.

Koopman, Robert, Zhi Wang and Shang-Jin Wei. 2009. “A World Factory in Global Production Chains: Estimating Imported Value Added in Exports by the People's Republic of China."Forthcoming in Robert Barro and Jong-Wha Lee, eds, Costs and Benefits of Economic Integration in Asia, Oxford University Press. 
Leamer, Edward (chair). 2006. “Analyzing the U.S. Content of Imports and the Foreign Content of Exports.” National Research Council, National Academy of Sciences. National Academies Press, Washington, DC.

Nordas, Hildegunn. 2005. "International Production Sharing: A Case for a Coherent Policy Framework.” Discussion Paper No. 11, World Trade Organization.

Pula, Gabor and Tuomas Peltonen. 2011. "Has Emerging Asia Decoupled? An Analysis of Production and Trade Linkages Using the Asian International Input-Output Table.” in Yin-Wong Cheung, Vikas Kakkar, Guonan Ma (ed.) The Evolving Role of Asia in Global Finance (Frontiers of Economics and Globalization, Volume 9), Emerald Group Publishing Limited, pp.255-286.

Simon, Carl and Lawrence Blume. 1994. Mathematics for Economists. W.W. Norton: New York.

Wang, Zhi, William Powers, and Shang-Jin Wei. 2009. "Value Chains in East Asian Production Networks.” USITC Working Paper No. 2009-10-C, October.

Yi, Kei-Mu. 2010. "Can Multistage Production Explain the Home Bias in Trade?" American Economic Review, 100(1):364-393.

Yi, Kei-Mu. 2003.“Can Vertical Specialization Explain the Growth of World Trade?” Journal of Political Economy, 111(1): 52-102 
Table 1 Share of intermediate inputs in electronic machinery imports, 2004

\begin{tabular}{|c|c|c|c|c|c|c|c|c|}
\hline \multirow[b]{3}{*}{ Country } & \multicolumn{4}{|c|}{ United States } & \multicolumn{4}{|c|}{ Japan } \\
\hline & \multirow[b]{2}{*}{ Value $^{\mathrm{a}}$} & \multicolumn{3}{|c|}{ Share of intermediate inputs(\%) } & \multirow[b]{2}{*}{ Value $^{\mathrm{a}}$} & \multicolumn{3}{|c|}{ Share of intermediate inputs(\%) } \\
\hline & & $\begin{array}{r}\text { Propor- } \\
\text { tion } \\
\end{array}$ & $\begin{array}{r}\mathrm{UN} \\
\mathrm{BEC}^{\mathrm{b}}\end{array}$ & $\begin{array}{r}\text { Asia } \\
\text { IO } \\
\end{array}$ & & $\begin{array}{r}\text { Propor } \\
\text {-tion } \\
\end{array}$ & $\begin{array}{r}\mathrm{UN} \\
\mathrm{BEC}^{\mathrm{c}}\end{array}$ & Asia IO \\
\hline & $(1)$ & $(2)$ & $(3)$ & $(4)$ & $(5)$ & (6) & $(7)$ & (8) \\
\hline EU & 13,405 & 54.2 & 65.0 & 58.3 & 2,551 & 46.2 & 47.8 & 53.5 \\
\hline Japan & 23,364 & 54.2 & 57.5 & 51.9 & & & & \\
\hline United States & & & & & 7,165 & 46.2 & 67.6 & 62.4 \\
\hline Hong Kong & 348 & 54.2 & 41.4 & 43 & 112 & 46.2 & 48.1 & 44.2 \\
\hline Korea & 18,718 & 54.2 & 42.4 & 43.2 & 6,244 & 46.2 & 75.0 & 66.6 \\
\hline Taiwan & 13,175 & 54.2 & 62.4 & 57.5 & 8,423 & 46.2 & 77.9 & 72.1 \\
\hline Singapore & 7,678 & 54.2 & 52.5 & 46.0 & 112 & 46.2 & 48.1 & 43.5 \\
\hline China & 57,357 & 54.2 & 33.5 & 36.6 & 20,088 & 46.2 & 13.0 & 30.8 \\
\hline Indonesia & 1,765 & 54.2 & 34.9 & 37.2 & 1,074 & 46.2 & 33.3 & 46.5 \\
\hline Malaysia & 21,035 & 54.2 & 49.2 & 46.6 & 5,638 & 46.2 & 59.6 & 45.1 \\
\hline Philippines & 3,245 & 54.2 & 82.2 & 71.0 & 4,999 & 46.2 & 73.0 & 60.8 \\
\hline Thailand & 4,787 & 54.2 & 30.4 & 39.5 & 3,901 & 46.2 & 60.0 & 38.9 \\
\hline India & 145 & 54.2 & 86.2 & 65.9 & 7 & 46.2 & 50.8 & 60.8 \\
\hline World Total & 201,526 & 54.2 & 47.1 & 45.9 & 65,563 & 46.2 & 51.5 & 47.9 \\
\hline Correlation with $A I O^{b}$ & $\mathrm{~N}=13$ & 0.00 & 0.98 & 1.00 & $\mathrm{~N}=13$ & 0.00 & 0.64 & 1.00 \\
\hline
\end{tabular}

Source: Authors estimate based on domestic supply in GTAP database and UNBEC.

${ }^{\mathrm{a}}$ Imports of both intermediate and final goods, in millions of U.S. dollars. 
Table 2 Decomposition of gross exports, 2004

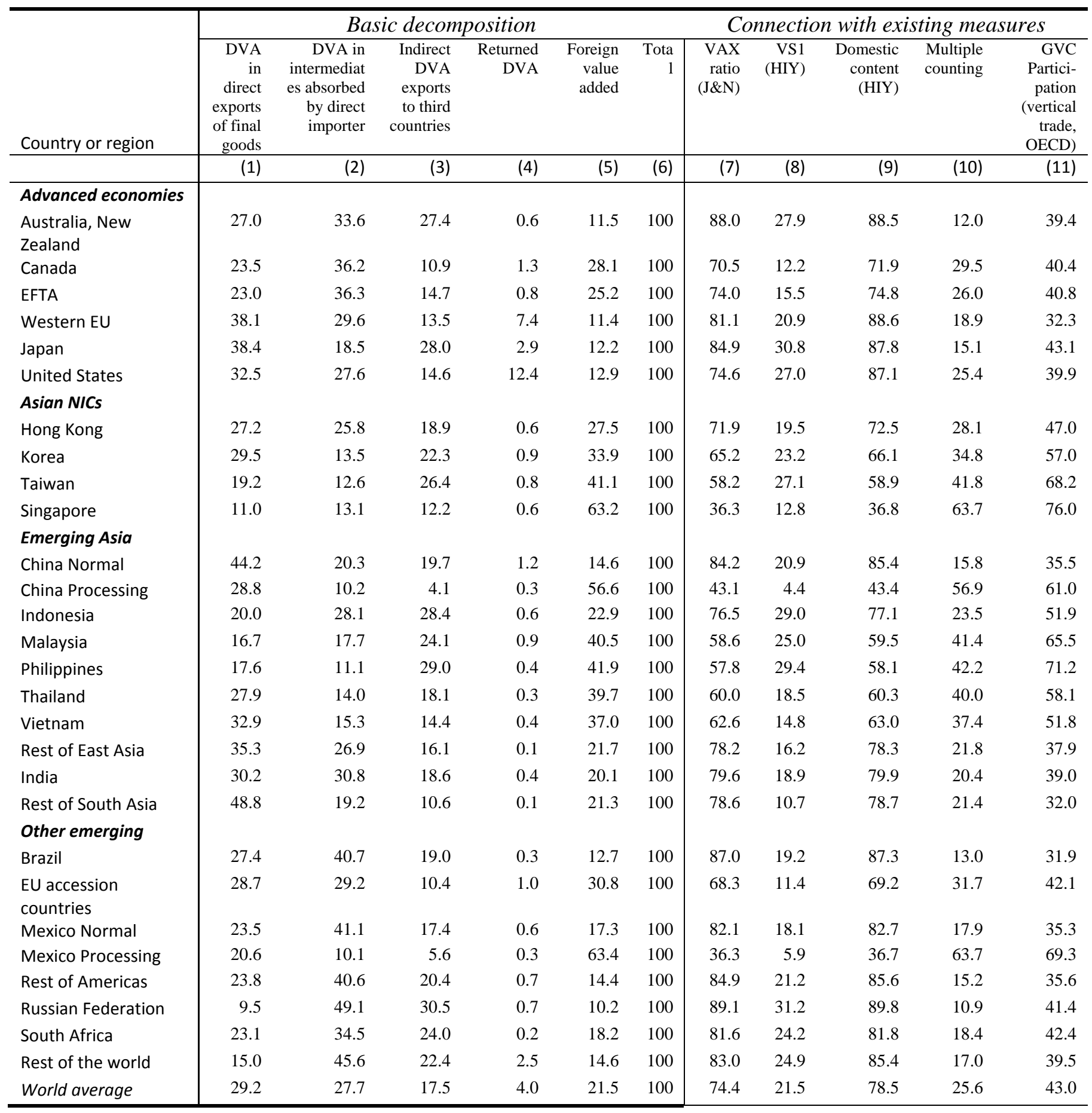

Source: Authors' estimates

Notes:All columns are expressed as a share of total gross exports. DVA refers to domestic value added.Country groupings follow IMF regions (www.imf.org/external/pubs/ft/weo/2010/01/weodata/groups.htm\#oem). 


\section{Table 3 Magnification of trade costs on final manufacturing goods exports from vertical}

specialization, 2004

\begin{tabular}{|c|c|c|c|c|c|c|c|c|c|c|c|c|}
\hline \multirow[t]{3}{*}{ Country or region } & \multicolumn{3}{|c|}{ Standard trade costs } & \multirow{2}{*}{$\begin{array}{c}\text { Foreign } \\
\text { content } \\
\text { share }\end{array}$} & \multicolumn{3}{|c|}{$\begin{array}{l}\text { Trade cost for imported } \\
\text { inputs }\end{array}$} & \multicolumn{3}{|c|}{ Magnification factor ${ }^{a}$} & \multirow{2}{*}{$\begin{array}{l}\text { Effec- } \\
\text { ctive } \\
\text { tariff } \\
\text { rate }^{b}\end{array}$} & \multirow{2}{*}{$\begin{array}{c}\text { Magnifi } \\
\text {-cation } \\
\text { ratio }\end{array}$} \\
\hline & $\begin{array}{c}\text { Trans- } \\
\text { port }\end{array}$ & Tariff & Total & & $\begin{array}{c}\text { Trans- } \\
\text { Port }\end{array}$ & Tariff & Total & $\begin{array}{c}\text { Trans- } \\
\text { port }\end{array}$ & Tariff & Total & & \\
\hline & (1) & $(2)$ & $\begin{array}{r}(3)= \\
(1)+(2)\end{array}$ & (4) & (5) & (6) & $\begin{array}{r}(7)= \\
(5)+(6)\end{array}$ & (8) & (9) & (10) & (11) & $\begin{array}{r}(12)= \\
(11) /(2)\end{array}$ \\
\hline \multicolumn{13}{|c|}{ Advanced economies } \\
\hline Aus-New Zealand & 3.7 & 4.4 & 8.1 & 21.4 & 1.0 & 0.9 & 1.8 & 1.1 & 1.1 & 1.2 & 7.0 & 1.6 \\
\hline Canada & 1.3 & 0.5 & 1.8 & 41.7 & 0.8 & 0.3 & 1.1 & 1.4 & 1.2 & 1.6 & 2.8 & 5.7 \\
\hline EFTA & 2.0 & 2.0 & 3.9 & 37.1 & 0.8 & 0.1 & 0.8 & 1.2 & 1.0 & 1.2 & 4.8 & 2.4 \\
\hline WEU & 3.4 & 4.6 & 7.9 & 12.4 & 0.4 & 0.2 & 0.6 & 1.1 & 1.0 & 1.1 & 6.4 & 1.4 \\
\hline Japan & 3.2 & 5.4 & 8.6 & 11.6 & 0.3 & 0.0 & 0.4 & 1.0 & 1.0 & 1.0 & 7.2 & 1.3 \\
\hline USA & 2.4 & 2.4 & 4.8 & 14.3 & 0.4 & 0.1 & 0.6 & 1.1 & 1.0 & 1.1 & 4.0 & 1.7 \\
\hline \multicolumn{13}{|l|}{ Asian NICs } \\
\hline Hong Kong & 4.4 & 8.5 & 12.9 & 41.6 & 1.8 & 0.0 & 1.8 & 1.1 & 1.0 & 1.1 & 16.3 & 1.9 \\
\hline Korea & 3.3 & 5.0 & 8.2 & 31.5 & 0.8 & 1.3 & 2.1 & 1.1 & 1.2 & 1.3 & 9.0 & 1.8 \\
\hline Taiwan & 4.0 & 3.3 & 7.3 & 41.6 & 1.3 & 1.6 & 2.8 & 1.2 & 1.2 & 1.4 & 7.7 & 2.3 \\
\hline Singapore & 2.9 & 2.1 & 5.0 & 70.5 & 1.8 & 0.0 & 1.8 & 1.4 & 1.0 & 1.4 & 10.5 & 5.0 \\
\hline \multicolumn{13}{|l|}{ Emerging Asia } \\
\hline China normal & 7.3 & 9.2 & 16.5 & 13.7 & 0.7 & 1.4 & 2.1 & 1.0 & 1.1 & 1.1 & 11.9 & 1.3 \\
\hline China processing & 4.7 & 3.3 & 8.0 & 53.8 & 1.7 & 0.0 & 1.7 & 1.2 & 1.0 & 1.2 & 9.3 & 2.8 \\
\hline Indonesia & 6.1 & 5.9 & 12.0 & 36.6 & 1.8 & 1.8 & 3.5 & 1.2 & 1.2 & 1.3 & 11.1 & 1.9 \\
\hline Malaysia & 3.5 & 2.1 & 5.6 & 46.3 & 1.6 & 2.9 & 4.4 & 1.3 & 1.5 & 1.8 & 6.7 & 3.2 \\
\hline Philippines & 3.8 & 3.3 & 7.1 & 42.2 & 1.5 & 1.3 & 2.7 & 1.2 & 1.2 & 1.4 & 7.8 & 2.3 \\
\hline Thailand & 5.2 & 4.2 & 9.4 & 45.8 & 1.7 & 4.6 & 6.3 & 1.2 & 1.5 & 1.7 & 10.5 & 2.5 \\
\hline Vietnam & 7.7 & 8.8 & 16.5 & 48.0 & 3.2 & 11.8 & 15.0 & 1.2 & 1.7 & 1.9 & 20.2 & 2.3 \\
\hline Rest of East Asia & 5.1 & 8.8 & 13.8 & 33.6 & 2.4 & 5.1 & 7.5 & 1.2 & 1.4 & 1.5 & 15.3 & 1.7 \\
\hline India & 5.2 & 6.7 & 11.8 & 20.4 & 1.0 & 3.2 & 4.2 & 1.1 & 1.3 & 1.4 & 10.0 & 1.5 \\
\hline Rest of South Asia & 6.0 & 6.6 & 12.6 & 26.0 & 1.9 & 3.9 & 5.8 & 1.2 & 1.3 & 1.5 & 10.7 & 1.6 \\
\hline \multicolumn{13}{|c|}{ Other emerging economies } \\
\hline Brazil & 4.5 & 3.6 & 8.1 & 15.6 & 0.6 & 1.6 & 2.2 & 1.1 & 1.2 & 1.3 & 5.7 & 1.6 \\
\hline EU accession & 3.9 & 1.4 & 5.3 & 35.3 & 1.2 & 0.6 & 1.8 & 1.2 & 1.1 & 1.3 & 3.9 & 2.8 \\
\hline Mexico processing & 1.2 & 0.3 & 1.5 & 63.2 & 1.2 & 0.0 & 1.2 & 1.8 & 1.0 & 1.8 & 3.5 & 11.8 \\
\hline Mexico normal & 3.6 & 2.3 & 5.9 & 12.8 & 0.5 & 0.9 & 1.4 & 1.1 & 1.2 & 1.2 & 4.0 & 1.7 \\
\hline Rest of America & 4.6 & 5.9 & 10.5 & 23.0 & 1.3 & 2.3 & 3.6 & 1.1 & 1.2 & 1.4 & 9.2 & 1.6 \\
\hline Russian federation & 5.5 & 4.0 & 9.5 & 20.0 & 1.0 & 1.8 & 2.7 & 1.1 & 1.2 & 1.3 & 6.5 & 1.6 \\
\hline South Africa & 4.2 & 3.7 & 7.9 & 22.6 & 0.9 & 1.6 & 2.6 & 1.1 & 1.2 & 1.3 & 6.3 & 1.7 \\
\hline Rest of the world & 5.1 & 2.1 & 7.2 & 27.6 & 1.5 & 2.4 & 3.9 & 1.2 & 1.3 & 1.5 & 4.7 & 2.3 \\
\hline
\end{tabular}

${ }^{a}$ Column (8) and (9) equals Columns (3)+(5) and (3)+(6) divided by column (3) respectively. Column (10) equals columns (8)+(9)-1.

${ }^{b}$ Column (11) equals Columns (2)+(6) divide by (100-column (4))/100. 


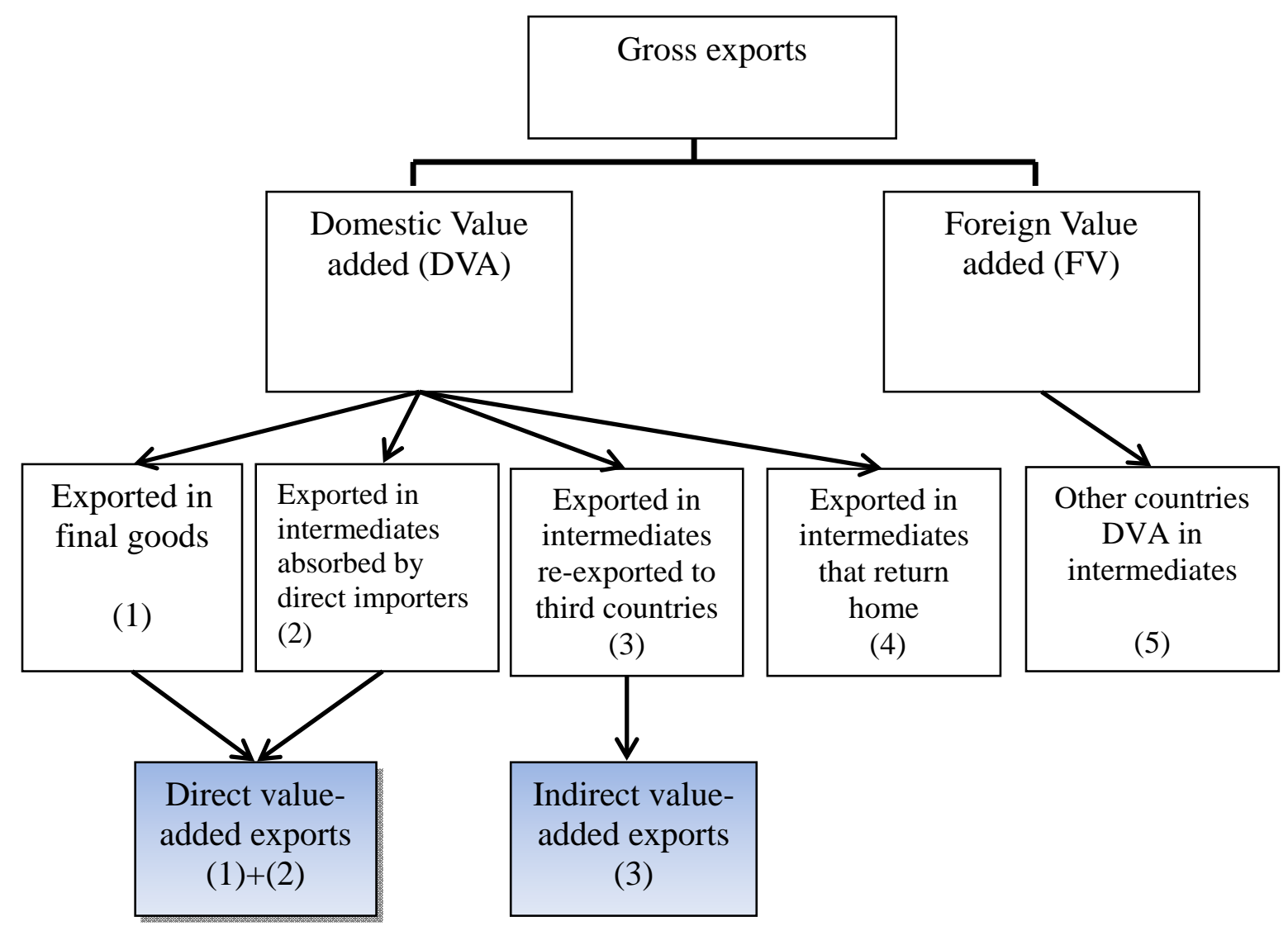

Note:

a.(4) are also labeled as VS1* by Daudin et al (2011).

b. (5) is labeled as VS, and (3) + (4) is labeled as VS1 by HIY (2001).

c. (4) and (5) involve value added that crosses national borders at least twice, and are the sources of multiple counting of value added in standard trade statistics.

d. The share of domestic content in a country's exports equals $(1)+(2)+(3)+(4)$

e. $(1)+(2)+(3)$ divided by gross exports is the VAX ratio for each country's exports to the world defined by Johnson and Noguera (2010). 
Figure 2 Global Value Chains - Position and Participation Indices
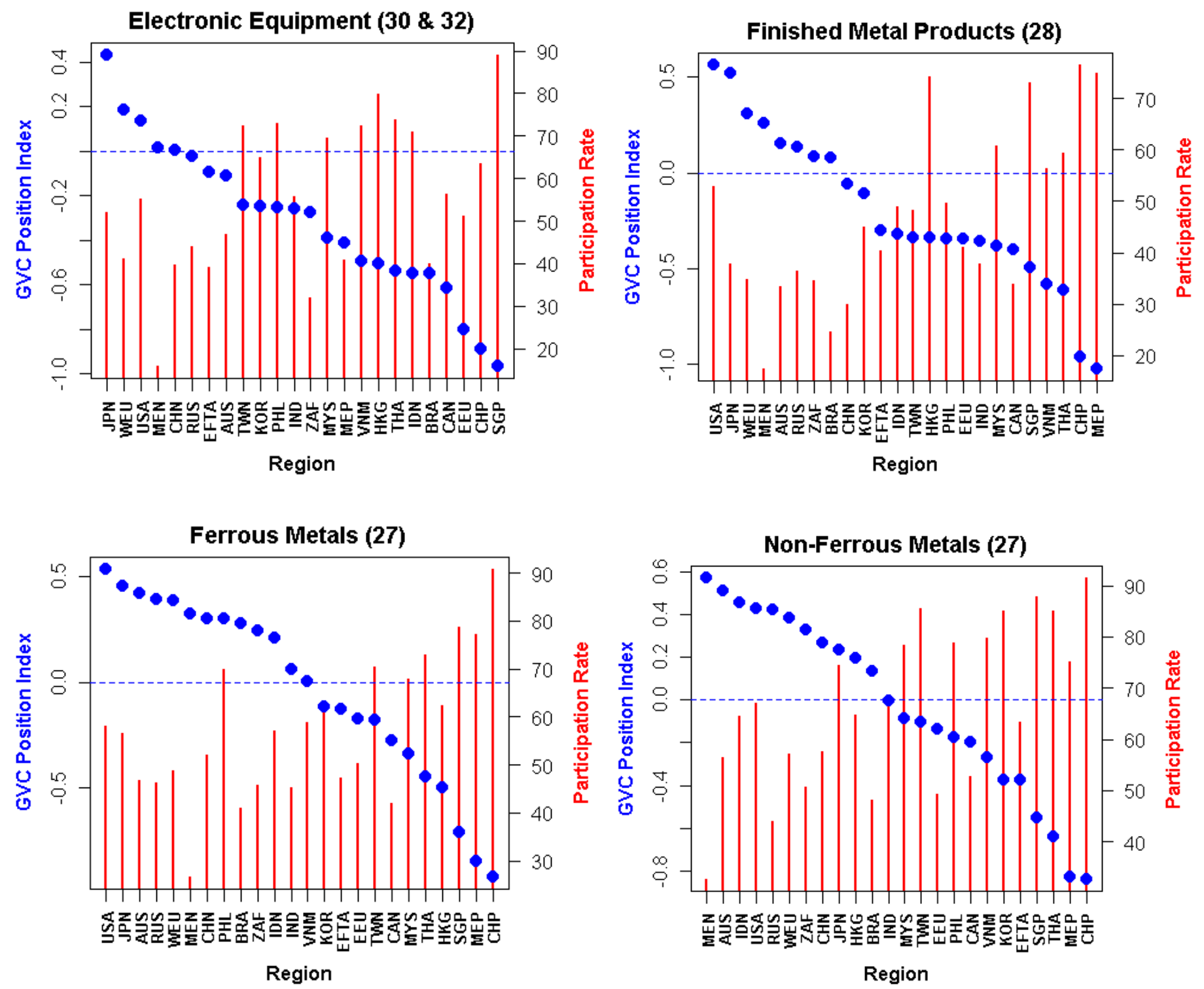

Paper Products and Publishing (21 \& 22)

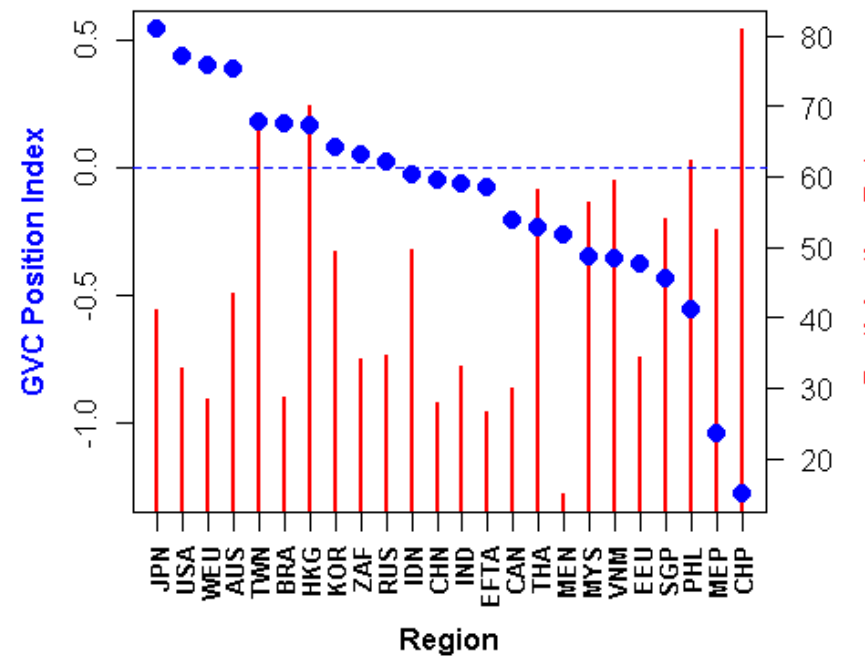

Chemical, Rubber and Plastic Products (24 \& 25)

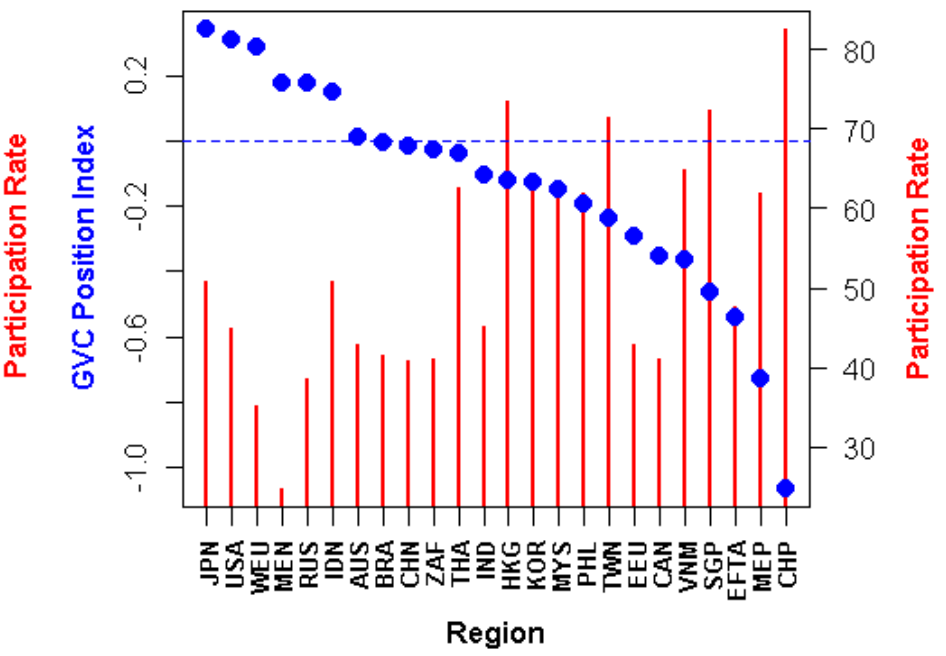


Figure 2: Global Value Chains - Position and Participation Indices - continued
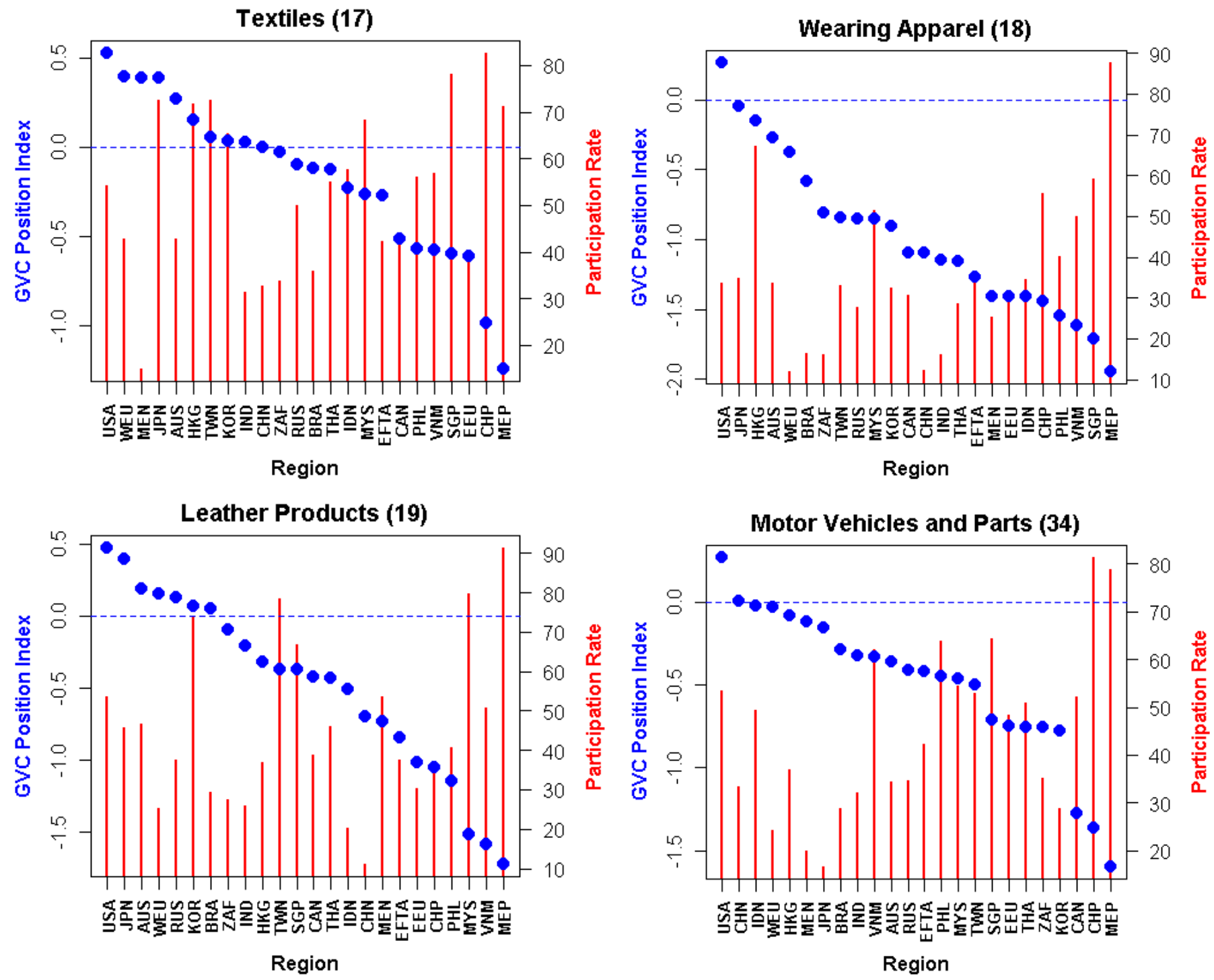

Machinery and Equipment (29, 31 \& 33)
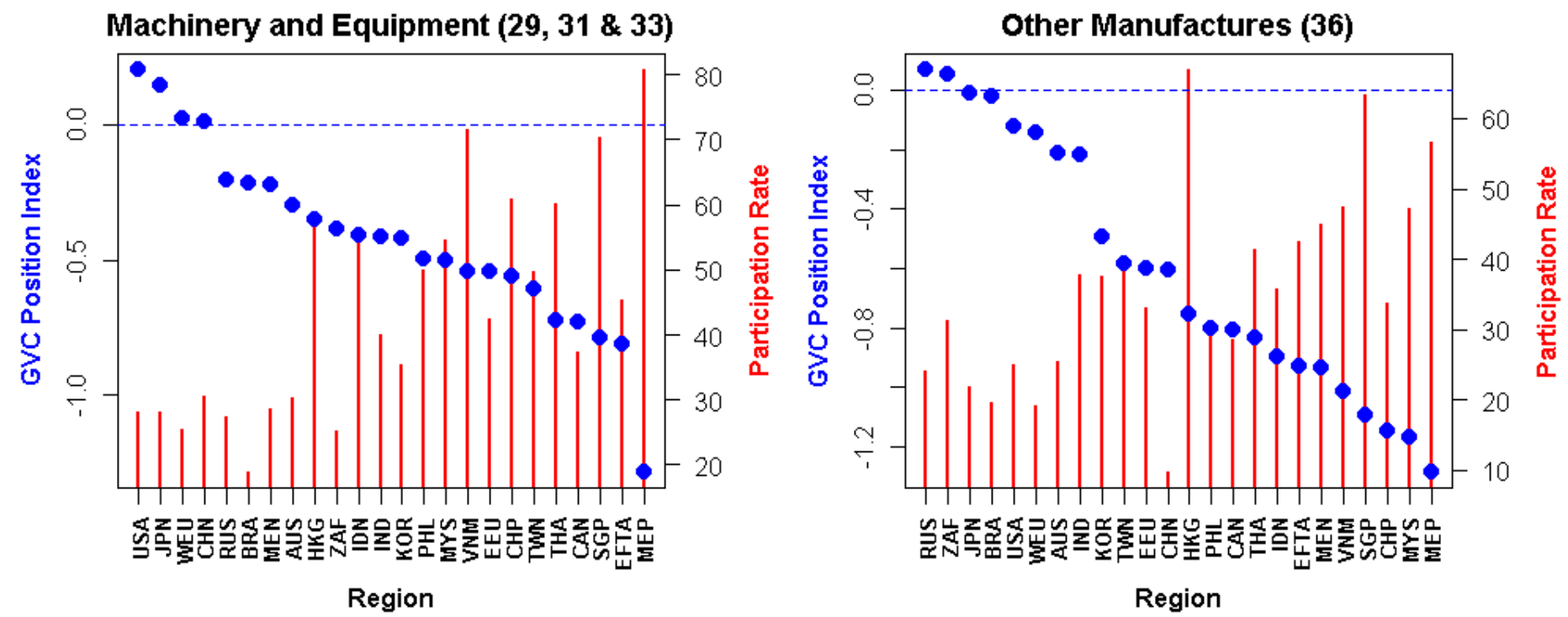
Figure 3 Value-added-adjusted Revealed Comparative Advantage Indicators

\section{Finished Metal Products (ISIC: 28)}

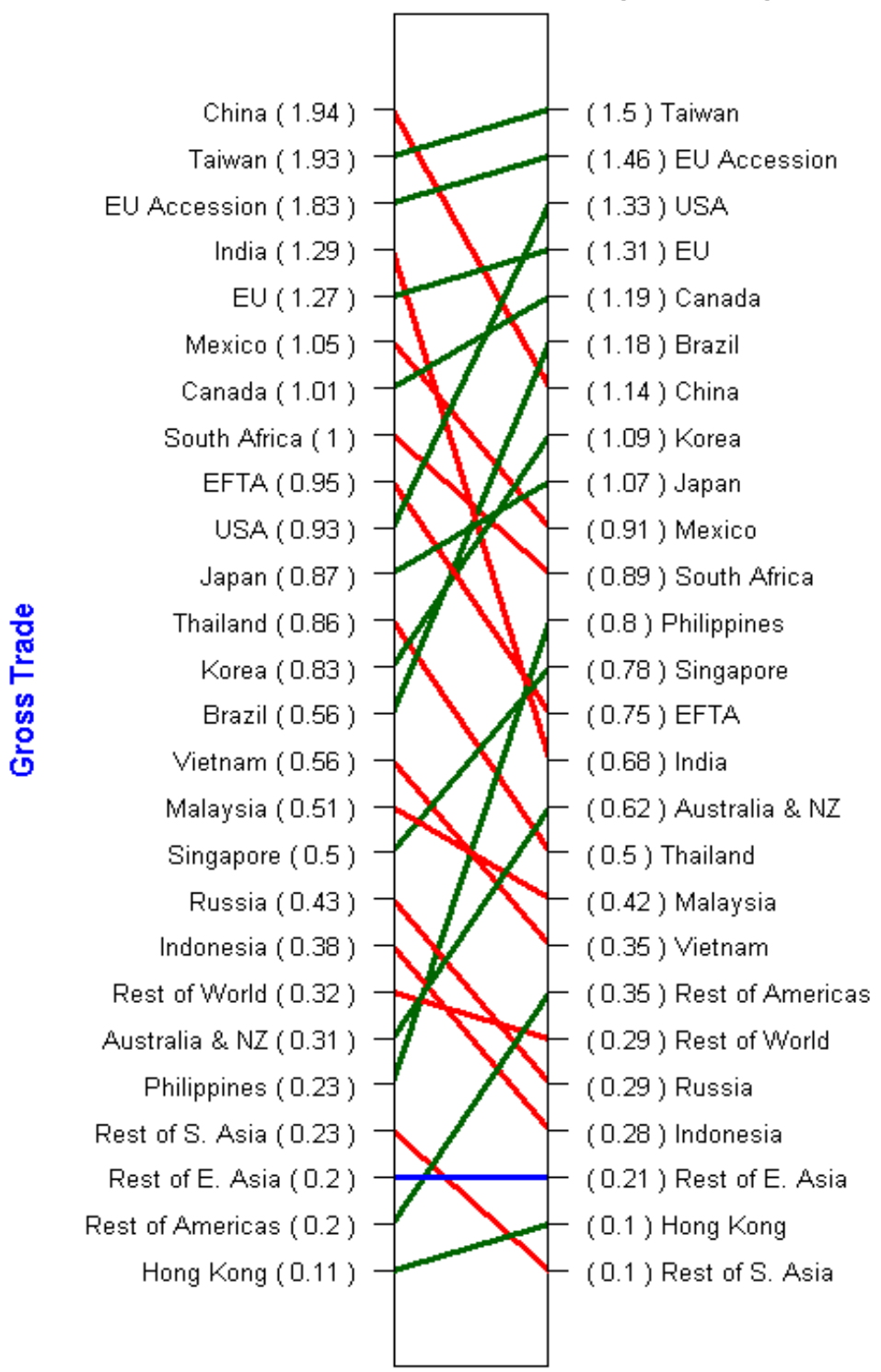

Real Estate, Renting and Business Activities (ISIC: K)

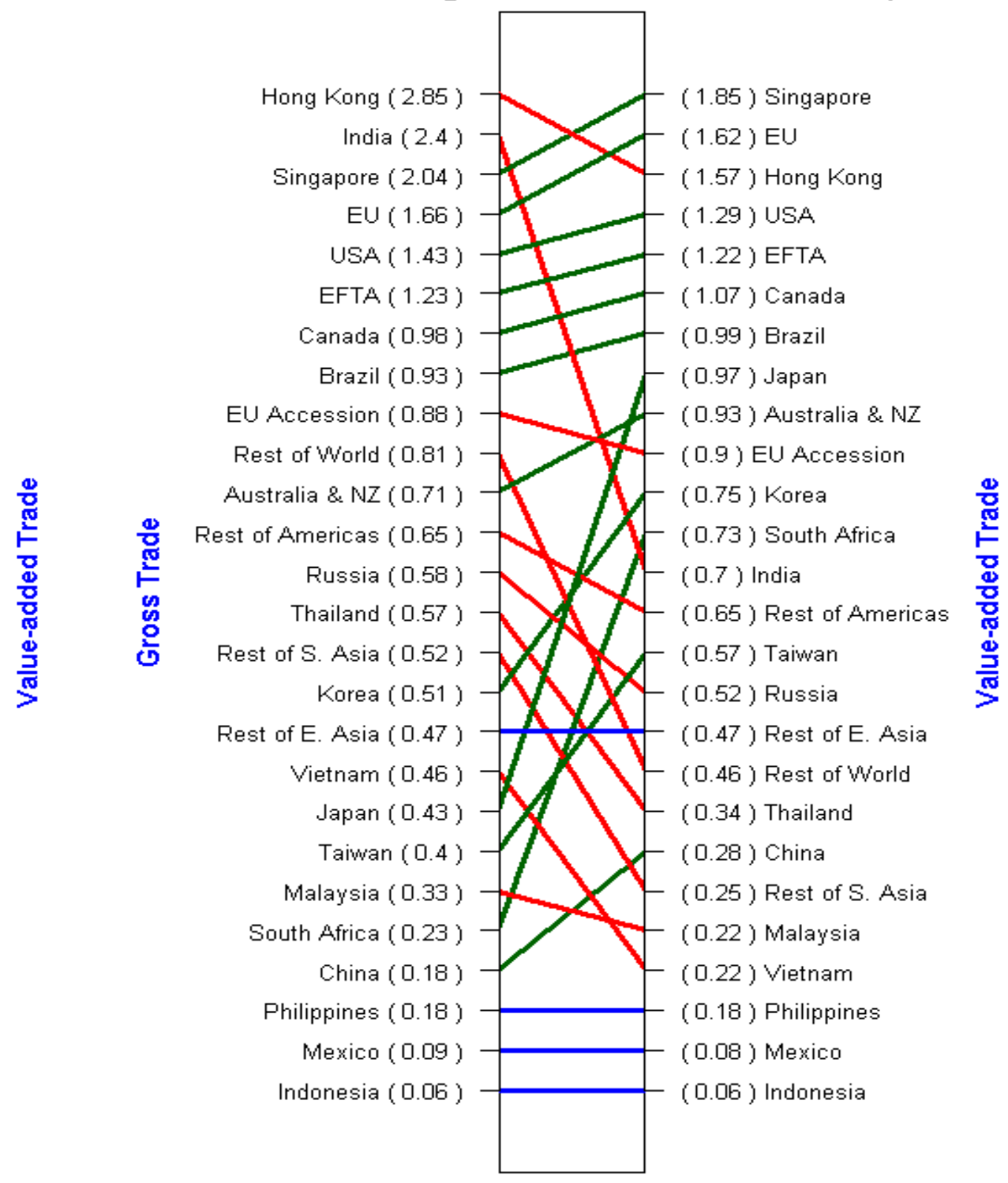


Figure 4: Gross and VA Balance of Trade, 2004

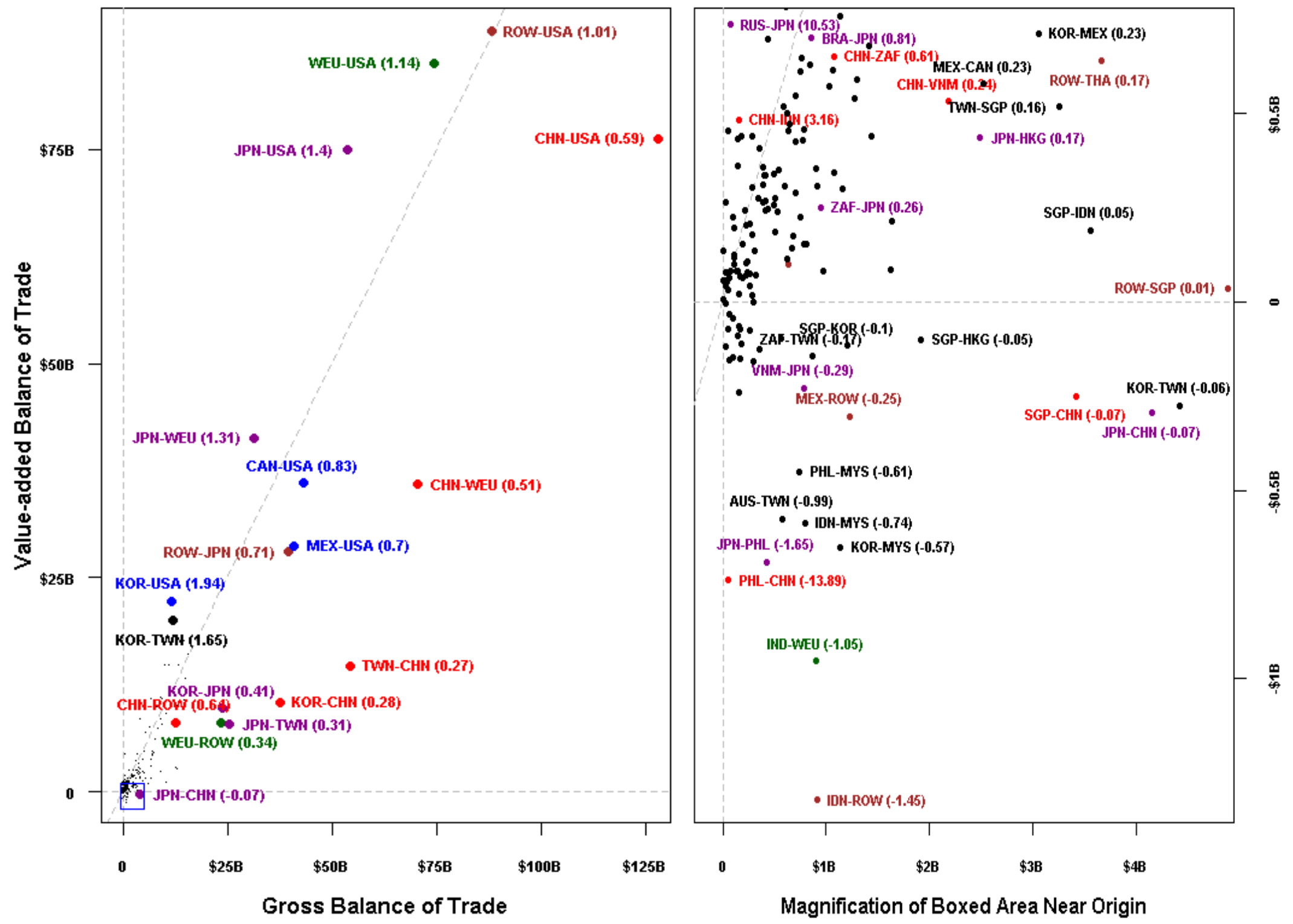

Note: The first country labeled in each pair is the surplus country while the second runs a deficit. Numbers in parentheses are the ratio of value-added to gross surplus. 


\section{For online publication only}

\section{Appendix A: Database construction and composition}

\section{A.1 Processing trade in China and Mexico}

The WTO reports that about 20\% of developing country exports come from Export Processing Zones (EPZs). Such processing regimes provide incentives to use imported intermediate inputs, provided that the resulting final goods are entirely exported. Processing trade can thus dramatically increase the imported content of exports relative to domestic use. Failure to account for processing imports can dramatically overstate the domestic content of exports (Koopman, Wang, and Wei, 2008).

To reflect the reality and importance of Export Processing Zones (EPZs) in emerging economies and their role in global value-added trade and production network, we incorporated an expandedChinese IO table with separate accounts for processing exports and a 2003 Mexican IO table with separate domestic and Maquiladora accounts. ${ }^{1}$ China and Mexico are the two largest users of export processing regimes in the developing world, and together account for about $85 \%$ of worldwide processing exports. ${ }^{2}$ We follow Koopman, Wang, and Wei (2008) to re-compute domestic and foreign value added in China and Mexico, but in a multi-country global setting, relaxing their assumption that all imports into China are $100 \%$ foreign value-added.

\section{A.2 Further comparison of end-use and proportional measures}

As shown in table A1, for most developing countries, the end-use method produces a lower intermediate share in exports. Developing countries (particularly Vietnam, China, South Asia, and Thailand) export substantially more final goods to their major export markets than what they supplied domestically. The exceptions are the natural-resource exporting countries such as Brazil andRussia—the end-use method produces higher intermediate shares in their exports.

\footnotetext{
${ }^{1}$ The Mexican table is from the Mexican statistical agencyInstitutoNacional de Estadística, Geografía e Informática (INEGI).

${ }^{2}$ During 2000-2008, China alone accounted for about $67 \%$ of all reported processing exports in the world while Mexico represents another 18\% (Maurer and Degain, 2010). Similarly, based on IMF BOP statistics provided by Andreas Maurer, we estimate that China and Mexico together accounted for about $80 \%$ of goods for processing in the world in 2005 and 2007.
} 
Appendix Table A1 Share of intermediate inputs in trade, proportion and end-use methods

\begin{tabular}{|c|c|c|c|c|c|c|}
\hline \multirow{3}{*}{ Country } & \multicolumn{3}{|c|}{ Gross exports } & \multicolumn{3}{|c|}{ Gross imports } \\
\hline & \multirow{2}{*}{$\begin{array}{l}\text { Value, billion } \\
\text { U.S. dollars }\end{array}$} & \multicolumn{2}{|c|}{ Share of intermediates (\%) } & \multirow{2}{*}{$\begin{array}{l}\text { Value, billion } \\
\text { U.S. dollars }\end{array}$} & \multicolumn{2}{|c|}{ Share of intermediates (\%) } \\
\hline & & Proportion & End-use & & Proportion & End-use \\
\hline (1) & $(2)$ & (3) & (4) & (5) & (6) & (7) \\
\hline \multicolumn{7}{|l|}{ Advanced economies } \\
\hline Australia, New Zealand & 122.5 & 71.7 & 69.4 & 131.5 & 56 & 50.2 \\
\hline Canada & 323.0 & 61 & 63.7 & 305.8 & 63 & 60.4 \\
\hline EFTA & 259.5 & 71.2 & 66.7 & 208.0 & 65.6 & 61.8 \\
\hline Western EU & $1,575.5$ & 60.4 & 57.2 & $1,624.2$ & 62.8 & 61.1 \\
\hline Japan & 618.9 & 60.4 & 56.7 & 513.9 & 64.2 & 61.9 \\
\hline United States & $1,062.3$ & 61.4 & 63.2 & $1,590.1$ & 57.2 & 54.7 \\
\hline \multicolumn{7}{|l|}{ Asian NICs } \\
\hline Hong Kong & 121.7 & 63.4 & 62.6 & 104.8 & 61.3 & 60.5 \\
\hline Korea & 283.1 & 63.7 & 57.5 & 245.1 & 81.2 & 76.6 \\
\hline Taiwan & 219.8 & 67.9 & 68.4 & 170.3 & 75.4 & 72.6 \\
\hline \multicolumn{7}{|l|}{ Emerging Asia } \\
\hline China & 670.6 & 54.6 & 43.1 & 568.8 & 82.6 & 77.4 \\
\hline Malaysia & 152.0 & 67.5 & 70.4 & 101.6 & 73.5 & 72.1 \\
\hline Philippines & 50.1 & 62 & 71.6 & 46.6 & 75.1 & 74.8 \\
\hline Thailand & 119.4 & 61.8 & 54.9 & 98.0 & 75.3 & 75.6 \\
\hline Vietnam & 32.3 & 55.8 & 42.7 & 34.5 & 72.9 & 72.1 \\
\hline Indonesia & 86.7 & 70.5 & 70.8 & 73.2 & 65.5 & 71 \\
\hline Rest of East Asia & 25.7 & 57.8 & 51.5 & 17.1 & 68.4 & 64.5 \\
\hline India & 99.9 & 59.2 & 63.5 & 121.1 & 75.8 & 81.9 \\
\hline South Asia & 36.0 & 47.1 & 36.5 & 51.3 & 56.2 & 60.6 \\
\hline \multicolumn{7}{|c|}{ Other emerging economies } \\
\hline Brazil & 113.0 & 63.5 & 68.7 & 77.1 & 67.4 & 67.1 \\
\hline EU accession countries & 273.7 & 58.2 & 57.9 & 306.1 & 66.9 & 64 \\
\hline Rest of Americas & 209.3 & 69.9 & 71.9 & 183.1 & 55.8 & 55.7 \\
\hline Mexico & 190.5 & 55.7 & 52.4 & 183.4 & 63.1 & 74.6 \\
\hline Russian Federation & 160.2 & 82.8 & 88.8 & 121.3 & 46.4 & 42.3 \\
\hline South Africa & 61.4 & 71 & 71.5 & 54.1 & 65.1 & 61 \\
\hline Rest of the world & 715.9 & 79.2 & 81.1 & 647.0 & 49.6 & 51.2 \\
\hline World & $7,733.4$ & 63.7 & 62.1 & $7,733.4$ & 63.7 & 62.1 \\
\hline
\end{tabular}

Source: Authors' estimates based on domestic supply in GTAP database and UN BEC end-use classification. 


\section{A.3 Regional composition of the ICIO database}

As described in section 3, the ICIO database constructed for this paper includes 24 additional countries or regions that, together with Mexico and China, covers all global trade and production. Table A2 lists the regions in the dataset along with the associated GTAP version 7 countries and regions.

\section{Appendix Table A2 Countries in database and corresponding GTAP regions}

\begin{tabular}{|c|c|}
\hline Country or region & Corresponding GTAP region(s) \\
\hline Australia, New Zealand & Australia, New Zealand \\
\hline Brazil & Brazil \\
\hline Canada & Canada \\
\hline China & China \\
\hline China normal & N/A \\
\hline China processing & N/A \\
\hline EFTA & Switzerland, Norway, Rest of EFTA \\
\hline EU accession & $\begin{array}{l}\text { Bulgaria, Cyprus, Czech Republic, Estonia, Hungary, Latvia, Lithuania, Malta, } \\
\text { Poland, Romania, Slovakia, Slovenia }\end{array}$ \\
\hline EU 15(Western EU) & $\begin{array}{l}\text { Austria, Belgium, Denmark, Finland, France, Germany, Greece, Ireland, Italy, } \\
\text { Luxembourg, Netherlands, Portugal, Spain, Sweden, UK }\end{array}$ \\
\hline Hong Kong & Hong Kong \\
\hline Indonesia & Indonesia \\
\hline India & India \\
\hline Japan & Japan \\
\hline Korea & Korea \\
\hline Mexico & Mexico \\
\hline Mexico normal & N/A \\
\hline Mexico processing & N/A \\
\hline Malaysia & Malaysia \\
\hline Philippines & Philippines \\
\hline Latin America and the & Argentina, Bolivia, Caribbean, Chile, Colombia, Costa Rica, Ecuador, Guatemala, \\
\hline Caribbean & $\begin{array}{l}\text { Nicaragua, Panama, Paraguay, Peru, Rest of Central America, Rest of North } \\
\text { America, Rest of South America, Uruguay, Venezuela }\end{array}$ \\
\hline Rest of world & $\begin{array}{l}\text { Albania, Armenia, Azerbaijan, Belarus, Botswana, Central Africa, Croatia, Egypt, } \\
\text { Ethiopia, Georgia, Iran, Islamic Republic of, Kazakhstan, Kyrgyzstan, Madagascar, } \\
\text { Malawi, Mauritius, Morocco, Mozambique, Nigeria, Rest of Eastern Africa, Rest of } \\
\text { E. Europe, Rest of Europe, Rest of Former Soviet Union, Rest of North Africa, Rest } \\
\text { of Oceania, Rest of South African Customs Union, Rest of Western Africa, Rest of } \\
\text { Western Asia, Senegal, South Central Africa, Tanzania, Tunisia, Turkey, Uganda, } \\
\text { Ukraine, Zambia, Zimbabwe }\end{array}$ \\
\hline Russian Federation & Russian Federation \\
\hline Singapore & Singapore \\
\hline South Asia & Bangladesh, Pakistan, Rest of South Asia, Sri Lanka \\
\hline Thailand & Thailand \\
\hline Taiwan & Taiwan \\
\hline United States & United States \\
\hline Vietnam & Vietnam \\
\hline Rest of East Asia & Cambodia, Laos, Myanmar, Rest of East Asia, Rest of Southeast Asia \\
\hline South Africa & South Africa \\
\hline
\end{tabular}




\section{Appendix B.1 Differences in GVC participation across major regions in the world}

The gross export decomposition reported in Table 2 of the main text shows that there are major differences in the extent of economic integration across different regions of the world. Figure A1 graphically displays these differences. Among developing countries, emerging East Asia has some of the lowest domestic value-added shares in exports. For example, for each dollar of Chinese exports in 2004, Chinese factors contributed about 64.3 cents, of which 51.7 cents was absorbed by China's direct importers, 11.9 cents was re-exported by those direct importers to third countries, and 0.8 cents returned to China. ${ }^{3}$ Other East Asian countries have even lower shares of domestic content in their exports. South Asian countries, such as India, have higher shares of domestic content in their exports, indicating their lower integration into global supply chains (on average across all goods and services). Among all emerging markets, the natural resource exporters, such as Russia, have the highest domestic content shares in their exports.

Most Asian developing countries (China, Vietnam, Thailand, South Asia, and the rest of East Asia), as well as Mexico and EU accession countries use substantial amounts of imported content to produce final goods exports, while most developed countries and natural resource exporters use imported value-added largely in the production of intermediate exports.

Advanced economies generally have high shares of domestic content in their exports, although a large portion of such value may return home via imports. The most notable feature of U.S. domestic value-added appears in column (5). It has, by far, the highest share of its own value-added returning home via imports (12.4\% of its gross exports and $8.3 \%$ of its gross imports in 2004). We look into the source structure of returned domestic value added in some detail in next sub-section.

Although Japan only has a moderate share of returned domestic value-added (2.9\%), it is the most integrated major economy as a supplier of intermediate inputs to exporters in other countries. Column (4) presents indirect value-added exports equal to IV in equation (24), excluding value added that has returned to home countries. (This is a cleaner measure of HIY's original VS1 measure.) For Japan, 28\% of its gross exports are indirect exported value-added to third countries. The high Japanese ranking on this measure is consistent with papers such as

\footnotetext{
${ }^{3}$ This estimate is higher than initial estimates of Chinese value added in exports, but consistent with estimates based on the most recent Chinese IO table. For example, Koopman Wang and Wei (2008) estimated domestic value-added share of 54\% using a 2002 China benchmark IO table. In contrast, Koopman, Wang and Wei (2011) uses the National Bureau of Statistics 2007 benchmark IO table - the same one employed in the current paper- to estimate that domestic value added composed $60.6 \%$ of Chinese gross exports.
} 
Dean, Lovely, and Mora (2009), which note that a high share of Japanese exports are processed in China and then sent as finished goods to developed countries such as the United States. This portion of value-added for the United States and Western $\mathrm{EU}^{4}$ considerably lower (14.6\% and $13.5 \%$ respectively).

Among emerging markets, natural resource exporters such as Russia and Indonesia export little of their domestic value added in final goods. These countries also tend to have high shares of domestic value-added absorbed by their direct importers, such as Russian exports of energy products absorbed by Europe, or Brazilian exports of primary products absorbed by the United States.

Emerging East Asia stands out with very low domestic value added in intermediates that are absorbed by their direct importers. Instead, these countries generally export substantial domestic value added in intermediate products that are subsequently re-exported to third countries. Although re-exports to third countries are generally the smallest of the four components of domestic content on average for the entire world, they represent much larger shares in East Asia and the so called Asian Newly Industrialized Countries (NICs). These East Asian economies are thus integrated into longer supply chains than other developing countries and are located in the middle of the production network, providing a large share of manufactured intermediates to both advanced and emerging economies. This result is consistent with singlesector case studies that have examined Asian supply chains for products such as electronics and automobiles. $^{5}$

Mexico and the EU accession countries appear most similar to East Asia economies among other emerging countries measured by their large share of foreign value-added in gross exports. They are distinguished from East Asia countries, however, by their large share of valueadded exports absorbed directly by their large immediate neighbors. Low income Asian countries (the rest of South and East Asian countries) as well as processing zones in China and Mexico have very high shares of value-added exports coming from direct exported final products, indicating that these economies are located in the end of global value chain.

The three largest advanced economies (the US, Western EU and Japan) have a relatively high share of domestic value-added embodied in their direct final goods exports in addition to their high share of indirect value-added exports through third counties including that which

\footnotetext{
4 “Western EU” refers throughout to the first 15 members of the EU; "EU Accession countries” refers to the next 12 members to join.

${ }^{5}$ For example, see Baldwin (2008) for disk drives and Nag et al. (2007) for automobiles.
} 
returns home, as we discussed earlier, indicating these economies are located in both upstream and downstream activities in the global production chain, consistent with the so called "smiling curve" phenomena found in the business economics literature.

Figure A1. Decomposition of Gross Exports, actual data, 2004

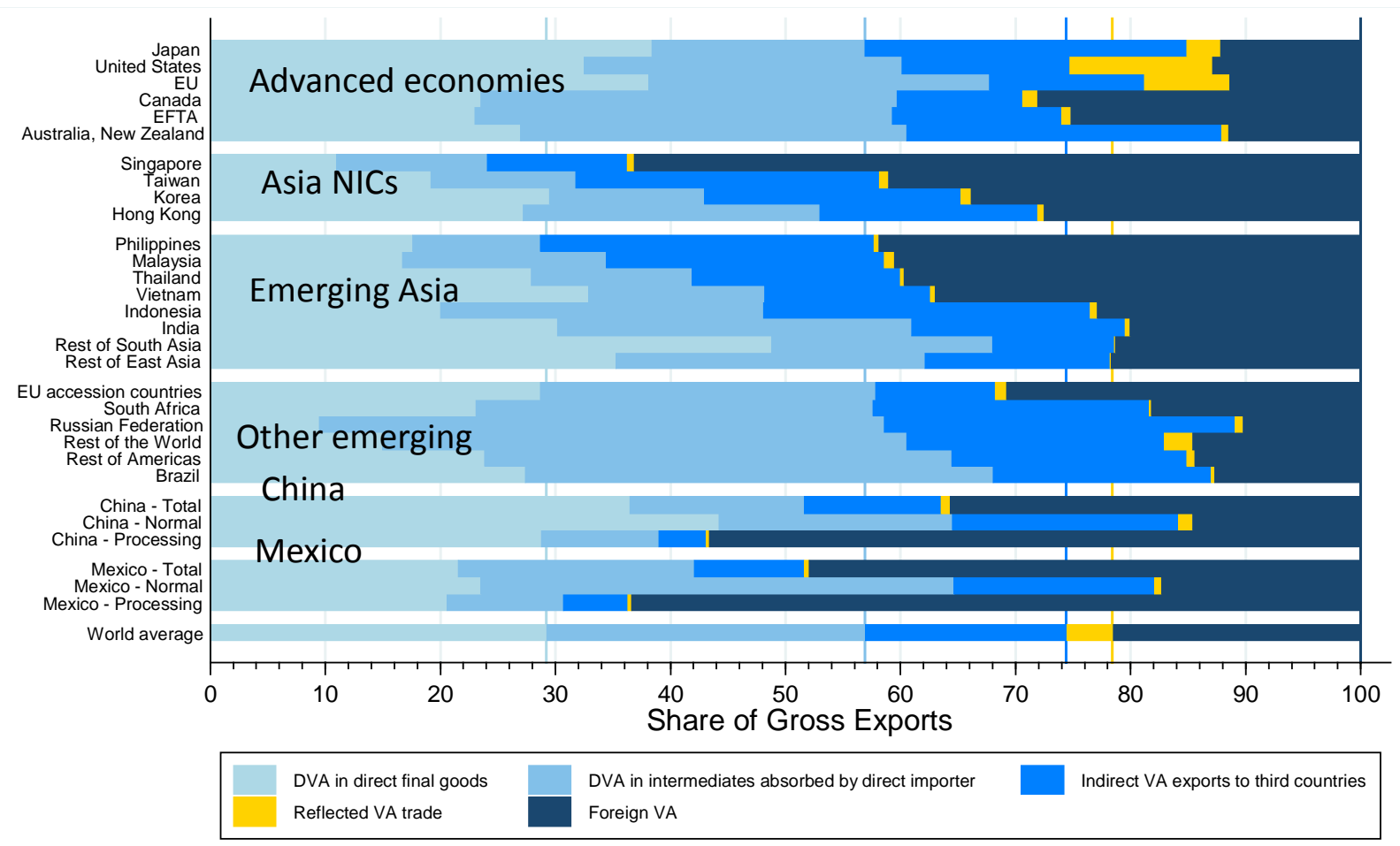




\section{B.2. Domestic value-added that returns home after processing abroad}

Table A3 reports the share of domestic value-added that has returned from abroad in bilateral gross imports of final goods for each of the three major advanced economies from each of the listed source countries (in columns 2, 4, and 6). It also reports the weight that each source country contributes to the returned domestic value-added totals (in columns 3, 5, and 7).

Each of these economies exhibits different patterns of production sharing in global supply chains. The United States contributes the highest share (10.0\%) of its own value added to its imports of final goods. One-quarter of U.S. imports from Canada consist of value added from the United States itself, and a huge $40 \%$ of U.S. final good imports from Mexico consist of its own value added. These two countries account for three quarters of all U.S. value added returned from abroad. However, although the United States has the world's highest share of its own value added return from abroad, it does so largely through North American regional supply chains. ${ }^{6}$ The EU contributes a lower share (7.8\%) of value to its own final goods imports. This returning value, however, is less concentrated among trading partners. It received about $50 \%$ of such value from its European neighbors, and moderate shares of its own value from many more countries than the United States, with moderate returned value shares from much of Asia (over 5\% from Vietnam, Hong Kong, Indonesia, Thailand, and Malaysia), and especially the "rest of the world" region (14.3\%). Japan imports the lowest share of its own value, at $4.3 \%$. The vast majority of its returned value comes from Asia, and China alone accounts for $58.5 \%$ of the total. Thus Japan, like the United States, largely receives its own value through regional supply chains, though through a more diverse set of partners.

\footnotetext{
${ }^{6}$ We also traced the returning value added one step further upstream for the United States, by computing the share of U.S. value added in other countries' exports of intermediate inputs to Canada and Mexico (which then return to the United States).The results indicate that most U.S. inputs that return home after assembly and finishing in North America travel through very short supply chains. Over $96 \%$ of the returned U.S. value from Canada and Mexico was exported directly to those countries, so relatively a very small share of this value travels through third countries.
} 
Table A3 Sources of domestic value added that returns home via final goods imports

\begin{tabular}{|c|c|c|c|c|c|c|}
\hline & \multicolumn{2}{|c|}{ United States } & \multicolumn{2}{|c|}{ Japan } & \multicolumn{2}{|c|}{ EU } \\
\hline Exporter & $\begin{array}{l}\text { U.S. share in } \\
\text { imports from } \\
\text { partner }\end{array}$ & $\begin{array}{c}\text { Partner's } \\
\text { share of } \\
\text { total }\end{array}$ & $\begin{array}{c}\text { Japanese share } \\
\text { in imports from } \\
\text { partner }\end{array}$ & $\begin{array}{c}\text { Partner's } \\
\text { share of } \\
\text { total }\end{array}$ & $\begin{array}{c}\text { EU share in } \\
\text { imports from } \\
\text { partner }\end{array}$ & $\begin{array}{c}\text { Partner's } \\
\text { share of } \\
\text { total }\end{array}$ \\
\hline$(1)$ & $(2)$ & (3) & $(4)$ & $(5)$ & $(6)$ & $(7)$ \\
\hline \multicolumn{7}{|l|}{ Advanced economies } \\
\hline Australia, New Zealand & 2.2 & 0.2 & 0.7 & 0.5 & 2.9 & 0.5 \\
\hline Canada & 24.7 & 32.4 & 0.7 & 0.2 & 3.3 & 0.6 \\
\hline EFTA & 3.0 & 0.4 & 0.9 & 0.5 & 19.6 & 18.1 \\
\hline EU & 2.1 & 4.4 & 0.9 & 3.9 & & 0.0 \\
\hline Japan & 2.0 & 2.1 & & 0.0 & 1.8 & 2.0 \\
\hline USA & & 0.0 & 1.1 & 4.4 & 2.8 & 6.3 \\
\hline \multicolumn{7}{|l|}{ Asian NICs } \\
\hline Korea & 5.4 & 2.2 & 5.1 & 4.7 & 4.3 & 2.3 \\
\hline Hong Kong & 3.1 & 0.6 & 4.3 & 3.0 & 5.6 & 1.0 \\
\hline Taiwan & 5.5 & 1.2 & 7.8 & 5.3 & 4.5 & 1.4 \\
\hline \multicolumn{7}{|l|}{ Emerging Asia } \\
\hline China & 4.2 & 7.0 & 8.7 & 58.0 & 4.1 & 6.7 \\
\hline Malaysia & 7.5 & 1.5 & 8.0 & 3.5 & 8.0 & 1.4 \\
\hline Indonesia & 3.5 & 0.3 & 5.6 & 1.7 & 5.0 & 0.6 \\
\hline Philippines & 3.7 & 0.2 & 9.6 & 3.2 & 5.1 & 0.3 \\
\hline Thailand & 4.4 & 0.8 & 8.3 & 6.2 & 5.3 & 1.4 \\
\hline Viet Nam & 2.8 & 0.2 & 4.0 & 1.0 & 5.1 & 0.7 \\
\hline Rest of East Asia & 2.3 & 0.1 & 1.3 & 0.1 & 4.2 & 0.4 \\
\hline India & 1.5 & 0.2 & 0.5 & 0.0 & 3.8 & 1.0 \\
\hline South Asia & 1.9 & 0.2 & 1.0 & 0.1 & 3.5 & 0.7 \\
\hline \multicolumn{7}{|c|}{ Other emerging economies } \\
\hline Brazil & 2.8 & 0.3 & 0.3 & 0.0 & 2.9 & 0.4 \\
\hline EU accession countries & 1.7 & 0.2 & 0.9 & 0.2 & 20.8 & 34.3 \\
\hline Mexico & 39.8 & 42.2 & 1.4 & 0.2 & 3.6 & 0.2 \\
\hline Rest of America & 6.3 & 1.9 & 0.5 & 0.2 & 3.2 & 1.2 \\
\hline Russia & 0.9 & 0.0 & 0.2 & 0.0 & 4.8 & 0.5 \\
\hline South Africa & 1.6 & 0.0 & 3.3 & 0.5 & 5.8 & 0.7 \\
\hline Rest of the world & 2.0 & 0.6 & 0.6 & 0.3 & 9.5 & 14.3 \\
\hline World & 10.0 & 100.0 & 4.3 & 100.0 & 7.8 & 100.0 \\
\hline \multicolumn{7}{|c|}{ Comparison of export processing regimes } \\
\hline China normal & 1.6 & 0.8 & 1.4 & 3.3 & 2.4 & 1.8 \\
\hline China processing & 5.3 & 6.2 & 12.8 & 54.7 & 5.6 & 4.9 \\
\hline Mexico normal & 5.1 & 0.7 & 0.3 & 0.0 & 1.7 & 0.0 \\
\hline Mexico processing & 44.9 & 41.5 & 2.9 & 0.2 & 5.2 & 0.2 \\
\hline
\end{tabular}

Source: Authors' estimates. 


\section{B.3 Position of countries within value chains: Evidence from broad sectors}

The export decomposition of this paper reported the components of domestic and foreign value added in exports but did not examine the sector generating such value in each country (except the RCA example in section 4.1). Appendix Table A4 breaks down three major valueadded components of gross exports into contributions by production factors employed in three broad sectors (raw materials, manufacturing, and services). ${ }^{7}$ Columns (2) through (4) present the value added to exports by these three broad sectors, as a share of total export value; while column (5) presents their sum, equal to the VAX ratio proposed by Johnson and Noguera (2010).They highlight the two types of countries that have high value-added to gross exports ratios. First, countries that export much of their value added from their raw materials sectors have the highest VAX ratios (e.g., Russia and "rest of world", which is dominated by petroleum exporters). Second, higher-income countries that export much of their value added from their services sectors, including Hong Kong, the EU, and the United States, also have relatively high overall VAX ratios, but lower than the natural resource exporters. Conversely, countries that export most of their value added from their manufacturing sectors, such as Taiwan, Mexico, and the Philippines, all have quite low VAX ratios.

Table A4 also reports the broad sectoral composition of foreign value added used in gross exports in columns (6) through (9). The production factors employed in the manufacturing sector contribute most of foreign value added in every country's gross exports.

Table A4 also reports the sectors that provide value-added in exports that are indirectly exported through third countries in columns (10) through (14). At the global level, value-added generated by production factors employed in manufacturing sectors accounts for about one-half of exports that are sent indirectly through third countries, and value-added generated by production factors employed in raw materials account for another one-sixth. Countries with high indirect exports may be more susceptible to global shocks (Bems, Johnson, and Yi, 2010). This may be particularly true for those with high share of indirect value-added exports in manufacturing (e.g., the Philippines, Japan, Taiwan, and Korea). These countries suffered major

\footnotetext{
${ }^{7}$ The value-added measures are computed after partitioning the VBE matrix into the three broad sectors. Sector results include all value-added produced by factors of production employed in each of these broad sectors, and exported by all sectors in the economy. See section 2.2. for further discussion of sectoral disaggregation.
} 
production and export downturns in 2008, even though some of their major direct export destinations (such as China) were less affected by the global slowdown.

Figure 2 in the main text shows whether countries are upstream and downstream in global supply chains for specific industries. For comparison to the literature, columns (14) through (17)present an alternative measure of each country's position in GVCs, the IV/FV ratio. These are analogous to the VS1/VS ratio presented by Daudin et al., 2010, though with additional detail on the domestic sector that provides value added to indirect exports. ${ }^{8}$ At the global level, IV and $\mathrm{FV}$ equal each other, therefore, the average IV/FV ratio is equal to 1 . A ratio larger than 1 indicates the country lies upstream in the global value-chain, either by providing raw materials (such as Russia) or by providing manufactured intermediates (such as Japan) or both. ${ }^{9}$ These countries, plus Australia, the United States, and the EU, have the highest IV/FV ratios. A ratio less than one means the country lies downstream in the global value-chain, using more intermediate inputs from other countries to provide final goods. Column (14) in table A4 shows that two groups have low IV/FV ratios: (1) Asian economies (both emerging and NICs), and (2) free trade partners neighboring large developed economies.

Further detail on the types of goods that countries provide to value chains allows us to separate these two types of countries. Columns (15) to (17) show that countries with higher than average IV/FV fall into one of two distinct groups. Some upstream emerging economies (e.g., Russia and Indonesia) produce primary products for global supply chains, while the upstream advanced economies produce both manufactured goods and services for these chains. (Almost uniformly, countries with high IV in manufacturing have high IV in services as well.) Only a few countries (Australia, Brazil, and Russia) have substantial indirect exports of both primary and non-primary products. ${ }^{10}$

\footnotetext{
${ }^{8}$ Columns (14) through (17) are calculated by dividing their respective column from (10) through (12) by column (9).

${ }^{9}$ Upstream here refers to the amount of value added provided relative to the amount received. Upstream in other literatures may denote the extent of primary product production. As we will see, some countries are upstream in both senses.

${ }^{10}$ Note that these three regions also have the lowest FV shares in column 9.
} 
Table A4 Decomposition of value-added exports from major sectors, share of gross exports, 2004

\begin{tabular}{|c|c|c|c|c|c|c|c|c|c|c|c|c|c|c|c|c|}
\hline \multirow{3}{*}{ Exporter } & \multicolumn{4}{|c|}{ Sector generating value-added exports ${ }^{a}$} & \multicolumn{4}{|c|}{$\begin{array}{l}\text { Sector composition of foreign value- } \\
\text { added in exports }\end{array}$} & \multicolumn{4}{|c|}{$\begin{array}{l}\text { Sector generating indirect value-added } \\
\text { exports through third countries }{ }^{c}\end{array}$} & \multicolumn{4}{|c|}{ Sectoral IV/ total FV ratio } \\
\hline & $\begin{array}{c}\text { Raw } \\
\text { materials }\end{array}$ & $\begin{array}{c}\text { Manu- } \\
\text { facturing }\end{array}$ & Services & Total & $\begin{array}{c}\text { Raw } \\
\text { materials }\end{array}$ & $\begin{array}{c}\text { Manu- } \\
\text { facturing }\end{array}$ & Services & Total & $\begin{array}{c}\text { Raw } \\
\text { materials }\end{array}$ & $\begin{array}{c}\text { Manu- } \\
\text { facturing }\end{array}$ & Services & Total & Total & $\begin{array}{c}\text { Raw } \\
\text { materials }\end{array}$ & $\begin{array}{c}\text { Manu- } \\
\text { facturing }\end{array}$ & Services \\
\hline & $(2)$ & (3) & (4) & (5) & $(6)$ & (7) & (8) & (9) & $(10)$ & $(11)$ & $(12)$ & (13) & (14) & $(15)$ & $(16)$ & $(17)$ \\
\hline \multicolumn{17}{|l|}{ Advanced economies } \\
\hline Australia, New Zealand & 30.3 & 21.1 & 36.5 & 88.0 & 3.6 & 5.6 & 2.3 & 11.5 & 9.8 & 8.7 & 9.4 & 27.9 & 2.4 & 0.86 & 0.76 & 0.82 \\
\hline Canada & 14.8 & 32.1 & 23.6 & 70.5 & 2.2 & 24.5 & 1.4 & 28.1 & 2.9 & 5.6 & 3.8 & 12.2 & 0.4 & 0.10 & 0.20 & 0.13 \\
\hline EFTA & 18.2 & 26.4 & 29.4 & 74.0 & 2.1 & 20.6 & 2.6 & 25.2 & 4.8 & 5.5 & 5.2 & 15.5 & 0.6 & 0.19 & 0.22 & 0.21 \\
\hline EU & 4.0 & 34.9 & 42.2 & 81.1 & 0.5 & 9.3 & 1.6 & 11.4 & 0.9 & 9.8 & 10.2 & 20.9 & 1.8 & 0.08 & 0.86 & 0.89 \\
\hline Japan & 1.1 & 49.9 & 34.0 & 84.9 & 0.1 & 11.6 & 0.6 & 12.2 & 0.3 & 18.8 & 11.7 & 30.8 & 2.5 & 0.03 & 1.53 & 0.96 \\
\hline United States & 5.5 & 32.4 & 36.7 & 74.6 & 0.6 & 10.7 & 1.7 & 12.9 & 1.7 & 13.9 & 11.4 & 27 & 2.1 & 0.13 & 1.07 & 0.88 \\
\hline \multicolumn{17}{|l|}{ Asian NICs } \\
\hline Korea & 1.5 & 45.3 & 18.5 & 65.2 & 0.2 & 32.0 & 1.6 & 33.9 & 0.4 & 17.0 & 5.8 & 23.2 & 0.7 & 0.01 & 0.50 & 0.17 \\
\hline Hong Kong & 2.7 & 11.7 & 57.5 & 71.9 & 0.1 & 11.3 & 16 & 27.5 & 1.3 & 5.8 & 12.4 & 19.5 & 0.7 & 0.05 & 0.21 & 0.45 \\
\hline Taiwan & 0.9 & 37.0 & 20.2 & 58.2 & 0.4 & 39.7 & 1.0 & 41.1 & 0.2 & 18.7 & 8.2 & 27.1 & 0.7 & 0.01 & 0.46 & 0.20 \\
\hline \multicolumn{17}{|l|}{ Emerging Asia } \\
\hline China & 9.3 & 37.5 & 16.0 & 62.8 & 1.0 & 33.8 & 0.8 & 35.7 & 1.6 & 7.6 & 3.0 & 12.2 & 0.3 & 0.05 & 0.21 & 0.08 \\
\hline Indonesia & 33.4 & 28.4 & 14.7 & 76.5 & 1.8 & 19.8 & 1.3 & 22.9 & 13.8 & 10.5 & 4.7 & 29 & 1.3 & 0.60 & 0.46 & 0.21 \\
\hline Malaysia & 13.0 & 32.2 & 13.4 & 58.6 & 2.3 & 36.2 & 1.9 & 40.5 & 4.5 & 15.7 & 4.9 & 25 & 0.6 & 0.11 & 0.39 & 0.12 \\
\hline Philippines & 6.4 & 38.5 & 12.8 & 57.8 & 1.2 & 38.8 & 1.8 & 41.9 & 1.6 & 21.8 & 5.9 & 29.4 & 0.7 & 0.04 & 0.52 & 0.14 \\
\hline Thailand & 10.9 & 31.0 & 18.1 & 60.0 & 2.5 & 34.3 & 2.9 & 39.7 & 2.2 & 11.4 & 4.9 & 18.5 & 0.5 & 0.06 & 0.29 & 0.12 \\
\hline Vietnam & 26.1 & 27.3 & 9.2 & 62.6 & 7.0 & 27.1 & 3.0 & 37.0 & 8.2 & 4.4 & 2.2 & 14.8 & 0.4 & 0.22 & 0.12 & 0.06 \\
\hline Rest of East Asia & 22.4 & 22.2 & 33.7 & 78.2 & 3.0 & 13.1 & 5.5 & 21.7 & 6.7 & 3.2 & 6.3 & 16.2 & 0.7 & 0.31 & 0.15 & 0.29 \\
\hline India & 17.2 & 35.2 & 27.2 & 79.6 & 1.0 & 16.5 & 2.6 & 20.1 & 4.3 & 8.9 & 5.8 & 18.9 & 0.9 & 0.21 & 0.44 & 0.29 \\
\hline South Asia & 14.0 & 30.8 & 33.8 & 78.6 & 1.3 & 18.0 & 2.1 & 21.3 & 1.8 & 3.8 & 5.0 & 10.7 & 0.5 & 0.09 & 0.18 & 0.24 \\
\hline \multicolumn{17}{|l|}{ Other emergingeconomies } \\
\hline Brazil & 22.8 & 37.7 & 26.5 & 87.0 & 2.9 & 9.0 & 0.8 & 12.7 & 4.7 & 8.6 & 6.0 & 19.2 & 1.5 & 0.37 & 0.68 & 0.47 \\
\hline EU accession countries & 5.7 & 35.7 & 26.8 & 68.3 & 1.2 & 26.7 & 2.9 & 30.8 & 0.8 & 6.2 & 4.3 & 11.4 & 0.4 & 0.03 & 0.20 & 0.14 \\
\hline Mexico & 12.8 & 33.9 & 4.7 & 51.3 & 5.6 & 41.7 & 0.6 & 48.0 & 2.4 & 6.5 & 0.6 & 9.6 & 0.2 & 0.05 & 0.14 & 0.01 \\
\hline Rest of Americas & 34.8 & 24.2 & 25.9 & 84.9 & 4.5 & 7.6 & 2.3 & 14.4 & 8.0 & 7.7 & 5.5 & 21.2 & 1.5 & 0.55 & 0.53 & 0.38 \\
\hline Russian Federation & 37.4 & 23.0 & 28.7 & 89.1 & 2.8 & 6.4 & 1.0 & 10.2 & 13.2 & 8.9 & 9.1 & 31.2 & 3.1 & 1.30 & 0.87 & 0.90 \\
\hline South Africa & 13.0 & 31.2 & 37.4 & 81.6 & 3.3 & 13.1 & 1.8 & 18.2 & 3.4 & 11.8 & 9.0 & 24.2 & 1.3 & 0.19 & 0.65 & 0.50 \\
\hline Rest of the world & 44.5 & 16.3 & 22.2 & 83.0 & 5.1 & 7.7 & 1.8 & 14.6 & 15.6 & 4.3 & 5.0 & 24.9 & 1.7 & 1.07 & 0.29 & 0.34 \\
\hline Average & 12.4 & 32.6 & 29.4 & 74.4 & 1.6 & 18.0 & 1.9 & 21.5 & 3.6 & 10.3 & 7.6 & 21.5 & 1.0 & 0.17 & 0.48 & 0.35 \\
\hline
\end{tabular}

Source: Authors' estimates.

Note: Value-added exports equals box (1)+(2)+(3) in figure 1;Foreign value equals box (5); Indirect VA exports equals box (3)+(4). 
Table A5 Decomposition of gross exports, selected sectors for the 10 largest exporters, 2004

\begin{tabular}{|c|c|c|c|c|c|c|c|c|c|c|c|}
\hline \multirow[b]{2}{*}{ Sector and exporter } & \multirow[b]{2}{*}{$\begin{array}{l}\text { Gross } \\
\text { exports }\end{array}$} & \multicolumn{6}{|c|}{ Basic decomposition } & \multicolumn{4}{|c|}{ Connection with existing measures } \\
\hline & & $\begin{array}{l}\text { DVA } \\
\text { in } \\
\text { direct } \\
\text { final } \\
\text { goods }\end{array}$ & $\begin{array}{c}\text { DVA in } \\
\text { interme- } \\
\text { diates } \\
\text { absorbed by } \\
\text { direct } \\
\text { importer }\end{array}$ & $\begin{array}{c}\text { Indirect } \\
\text { DVA } \\
\text { exports } \\
\text { to third } \\
\text { countries }\end{array}$ & $\begin{array}{l}\text { Reflected } \\
\text { DVA }\end{array}$ & $\begin{array}{l}\text { Foreign } \\
\text { VA }\end{array}$ & Total & $\begin{array}{l}\text { Share } \\
\text { of VS1 }\end{array}$ & $\begin{array}{c}\text { Domestic } \\
\text { content }\end{array}$ & $\begin{array}{l}\text { Multiple } \\
\text { counting }\end{array}$ & $\begin{array}{l}\text { GVC } \\
\text { partici- } \\
\text { pation } \\
\text { (vertical } \\
\text { trade) }\end{array}$ \\
\hline & & $(1)$ & $(2)^{a}$ & $(3)^{a}$ & $(4)^{\mathrm{a}}$ & (5) & (6) & (8) & (9) & $(10)$ & $(11)$ \\
\hline Western EU & 35,743 & 17.5 & 47.6 & 13.0 & 10.7 & 11.1 & 100.0 & 23.8 & 88.9 & 21.9 & 34.9 \\
\hline United States & 17,766 & 12.9 & 34.2 & 13.1 & 29.0 & 10.8 & 100.0 & 42.0 & 89.2 & 39.8 & 52.8 \\
\hline China Normal & 17,457 & 23.6 & 46.5 & 13.0 & 0.8 & 16.0 & 100.0 & 13.8 & 84.0 & 16.8 & 29.8 \\
\hline Japan & 9,631 & 8.2 & 53.9 & 26.9 & 2.6 & 8.3 & 100.0 & 29.6 & 91.7 & 10.9 & 37.9 \\
\hline China Processing & 5,864 & 9.9 & 13.6 & 6.7 & 0.1 & 69.7 & 100.0 & 6.8 & 30.3 & 69.8 & 76.5 \\
\hline EFTA & 4,403 & 12.6 & 47.1 & 12.5 & 0.6 & 27.2 & 100.0 & 13.1 & 72.8 & 27.8 & 40.3 \\
\hline Korea & 4,202 & 12.1 & 43.0 & 19.1 & 0.5 & 25.3 & 100.0 & 19.6 & 74.7 & 25.8 & 44.9 \\
\hline \multicolumn{12}{|c|}{ Motor Vehicles and parts } \\
\hline Western EU & 148,265 & 58.0 & 17.7 & 6.0 & 5.6 & 12.7 & 100.0 & 11.6 & 87.3 & 18.3 & 24.3 \\
\hline Japan & 119,896 & 65.1 & 18.1 & 6.3 & 0.4 & 10.0 & 100.0 & 6.7 & 90.0 & 10.4 & 16.7 \\
\hline United States & 80,619 & 34.5 & 12.0 & 5.4 & 29.6 & 18.5 & 100.0 & 35.0 & 81.5 & 48.1 & 53.5 \\
\hline Canada & 64,730 & 37.2 & 10.8 & 1.2 & 0.5 & 50.3 & 100.0 & 1.7 & 49.7 & 50.8 & 52.0 \\
\hline \multicolumn{12}{|c|}{ Electronic Machinery } \\
\hline China Processing & 161,070 & 28.4 & 8.0 & 6.5 & 0.0 & 57.1 & 100.0 & 6.5 & 42.9 & 57.1 & 63.6 \\
\hline Japan & 121,734 & 24.6 & 23.5 & 34.2 & 4.2 & 13.6 & 100.0 & 38.4 & 86.4 & 17.7 & 51.9 \\
\hline United States & 110,294 & 23.3 & 21.7 & 18.0 & 14.0 & 23.1 & 100.0 & 31.9 & 76.9 & 37.1 & 55.0 \\
\hline Western EU & 92,232 & 37.5 & 21.3 & 15.7 & 9.4 & 16.1 & 100.0 & 25.1 & 83.9 & 25.5 & 41.2 \\
\hline Korea & 91,101 & 21.8 & 13.3 & 22.4 & 0.8 & 41.8 & 100.0 & 23.1 & 58.2 & 42.5 & 64.9 \\
\hline Taiwan & 81,163 & 12.3 & 15.4 & 25.8 & 0.3 & 46.2 & 100.0 & 26.1 & 53.8 & 46.6 & 72.3 \\
\hline Malaysia & 74,746 & 15.9 & 14.6 & 19.3 & 0.4 & 49.8 & 100.0 & 19.7 & 50.2 & 50.2 & 69.5 \\
\hline Singapore & 53,458 & 5.7 & 5.3 & 7.8 & 0.1 & 81.1 & 100.0 & 7.9 & 18.9 & 81.2 & 89.0 \\
\hline Mexico processing & 31,042 & 39.8 & 19.5 & 10.9 & 0.1 & 29.8 & 100.0 & 10.9 & 70.2 & 29.8 & 40.7 \\
\hline Philippines & 30,204 & 9.5 & 17.5 & 25.7 & 0.2 & 47.1 & 100.0 & 25.9 & 52.9 & 47.3 & 73.0 \\
\hline
\end{tabular}

Note: Columns (1) through (11) are expressed as a share of total gross exports. Column numbering reflects table 2 in main text.

${ }^{a}$ First order approximations 


\section{Table A5 Decomposition of gross exports, selected sectors for the 10 largest exporters, 2004- Continued}

\begin{tabular}{|c|c|c|c|c|c|c|c|c|c|c|c|}
\hline \multirow[b]{2}{*}{$\begin{array}{l}\text { Sector and } \\
\text { exporter }\end{array}$} & \multirow[b]{2}{*}{$\begin{array}{l}\text { Gross } \\
\text { exports }\end{array}$} & \multicolumn{6}{|c|}{ Basic decomposition } & \multicolumn{4}{|c|}{ Connection with existing measures } \\
\hline & & $\begin{array}{l}\text { DVA } \\
\text { in } \\
\text { direct } \\
\text { final } \\
\text { goods }\end{array}$ & $\begin{array}{c}\text { DVA in } \\
\text { interme- } \\
\text { diates } \\
\text { absorbed by } \\
\text { direct } \\
\text { importer } \\
\end{array}$ & $\begin{array}{c}\text { Indirect } \\
\text { DVA } \\
\text { exports } \\
\text { to third } \\
\text { countries }\end{array}$ & $\begin{array}{c}\text { Reflected } \\
\text { DVA }\end{array}$ & $\begin{array}{l}\text { Foreign } \\
\text { VA }\end{array}$ & Total & $\begin{array}{l}\text { Share } \\
\text { of VS1 }\end{array}$ & $\begin{array}{c}\text { Domestic } \\
\text { content }\end{array}$ & $\begin{array}{l}\text { Multiple } \\
\text { counting }\end{array}$ & $\begin{array}{l}\text { GVC } \\
\text { partici- } \\
\text { pation } \\
\text { (vertical } \\
\text { trade) }\end{array}$ \\
\hline & & $(1)$ & $(2)^{a}$ & $(3)^{\mathrm{a}}$ & $(4)^{\mathrm{a}}$ & (5) & (6) & (8) & (9) & $(10)$ & (11) \\
\hline Western EU & 13,477 & 75.0 & 13.5 & 2.1 & 1.2 & 8.2 & 100 & 3.3 & 91.8 & 9.4 & 11.6 \\
\hline Australia \& NZ & 13,288 & 75.6 & 12.2 & 4.0 & 0.1 & 8.2 & 100 & 4.1 & 91.8 & 8.3 & 12.3 \\
\hline USA & 8,060 & 55.7 & 31.3 & 3.5 & 2.6 & 7.0 & 100 & 6.1 & 93.0 & 9.6 & 13.0 \\
\hline Brazil & 6,556 & 88.8 & 3.7 & 0.6 & 0.0 & 6.9 & 100 & 0.6 & 93.1 & 6.9 & 7.5 \\
\hline EFTA & 954 & 54.5 & 15.8 & 2.7 & 0.1 & 26.9 & 100 & 2.8 & 73.1 & 27.0 & 29.8 \\
\hline Thailand & 910 & 78.4 & 2.9 & 1.2 & 0.0 & 17.6 & 100 & 1.2 & 82.4 & 17.6 & 18.7 \\
\hline India & 629 & 65.0 & 24.1 & 4.2 & 0.1 & 6.6 & 100 & 4.3 & 93.4 & 6.7 & 10.9 \\
\hline \multicolumn{12}{|c|}{ Other Food Products } \\
\hline Western EU & 29,390 & 62.0 & 22.7 & 4.1 & 2.5 & 8.7 & 100 & 6.6 & 91.3 & 11.2 & 15.3 \\
\hline USA & 19,365 & 52.7 & 28.5 & 5.9 & 5.5 & 7.5 & 100 & 11.4 & 92.5 & 13.0 & 18.9 \\
\hline Brazil & 10,052 & 30.8 & 49.3 & 10.1 & 0.1 & 9.8 & 100 & 10.2 & 90.2 & 9.9 & 20.0 \\
\hline Canada & 9,492 & 61.5 & 14.7 & 3.0 & 0.2 & 20.7 & 100 & 3.2 & 79.3 & 20.9 & 23.9 \\
\hline \multicolumn{12}{|c|}{ Beverages and Tobacco } \\
\hline Western EU & 19,654 & 81.8 & 7.6 & 1.9 & 0.9 & 7.9 & 100 & 2.8 & 92.1 & 8.8 & 10.7 \\
\hline USA & 4,644 & 81.6 & 6.4 & 1.5 & 3.5 & 7.1 & 100 & 5.0 & 93.0 & 10.6 & 12.1 \\
\hline Australia \& NZ & 2,860 & 81.0 & 6.9 & 2.0 & 0.0 & 10.1 & 100 & 2.0 & 89.9 & 10.2 & 12.1 \\
\hline Mexico processing & 1,365 & 13.3 & 0.0 & 0.0 & 0.0 & 86.7 & 100 & 0.0 & 13.3 & 86.7 & 86.7 \\
\hline Canada & 1,315 & 67.6 & 15.0 & 3.5 & 0.1 & 13.9 & 100 & 3.6 & 86.1 & 14.0 & 17.4 \\
\hline EU Accession & 1,204 & 68.0 & 8.5 & 2.2 & 0.1 & 21.2 & 100 & 2.3 & 78.8 & 21.3 & 23.5 \\
\hline South Africa & 1,143 & 78.3 & 7.5 & 2.2 & 0.0 & 11.9 & 100 & 2.3 & 88.1 & 11.9 & 14.2 \\
\hline Singapore & 834 & 53.0 & 0.7 & 0.3 & 0.0 & 46.0 & 100 & 0.4 & 54.0 & 46.1 & 46.4 \\
\hline China normal & 804 & 84.1 & 6.7 & 1.5 & 0.1 & 7.6 & 100 & 1.6 & 92.4 & 7.7 & 9.2 \\
\hline Mexico normal & 794 & 95.9 & 1.1 & 0.4 & 0.0 & 2.6 & 100 & 0.4 & 97.4 & 2.6 & 3.0 \\
\hline
\end{tabular}


Table A5 Decomposition of gross exports, selected sectors for the 10 largest exporters, 2004Continued

\begin{tabular}{|c|c|c|c|c|c|c|c|c|c|c|c|}
\hline \multirow[b]{2}{*}{$\begin{array}{l}\text { Sector and } \\
\text { exporter }\end{array}$} & \multirow[b]{2}{*}{$\begin{array}{l}\text { Gross } \\
\text { exports }\end{array}$} & \multicolumn{6}{|c|}{ Basic decomposition } & \multicolumn{4}{|c|}{ Connection with existing measures } \\
\hline & & $\begin{array}{l}\text { DVA } \\
\text { in } \\
\text { direct } \\
\text { final } \\
\text { goods }\end{array}$ & $\begin{array}{c}\text { DVA in } \\
\text { interme- } \\
\text { diates } \\
\text { absorbed by } \\
\text { direct } \\
\text { importer } \\
\end{array}$ & $\begin{array}{c}\text { Indirect } \\
\text { DVA } \\
\text { exports } \\
\text { to third } \\
\text { countries }\end{array}$ & $\begin{array}{l}\text { Reflected } \\
\text { DVA }\end{array}$ & $\begin{array}{l}\text { Foreign } \\
\text { VA }\end{array}$ & Total & $\begin{array}{l}\text { Share } \\
\text { of VS1 }\end{array}$ & $\begin{array}{c}\text { Domestic } \\
\text { content }\end{array}$ & $\begin{array}{l}\text { Multiple } \\
\text { counting }\end{array}$ & $\begin{array}{l}\text { GVC } \\
\text { partici- } \\
\text { pation } \\
\text { (vertical } \\
\text { trade) }\end{array}$ \\
\hline & & $(2)^{\mathrm{a}}$ & $(3)^{\mathrm{a}}$ & $(4)^{\mathrm{a}}$ & (5) & (6) & (8) & (9) & (10) & (11) & (1) \\
\hline Western EU & 34,819 & 19.7 & 37.6 & 14.1 & 16.9 & 11.8 & 100 & 30.9 & 88.2 & 28.7 & 42.7 \\
\hline China normal & 34,804 & 45.4 & 21.9 & 15.9 & 0.5 & 16.3 & 100 & 16.4 & 83.7 & 16.8 & 32.7 \\
\hline USA & 15,052 & 13.9 & 31.9 & 10.5 & 31.8 & 11.9 & 100 & 42.3 & 88.1 & 43.7 & 54.3 \\
\hline Korea & 12,987 & 7.7 & 27.0 & 33.2 & 0.8 & 31.3 & 100 & 34.0 & 68.7 & 32.1 & 65.3 \\
\hline Japan & 7,672 & 2.3 & 25.2 & 41.0 & 10.9 & 20.6 & 100 & 51.9 & 79.4 & 31.5 & 72.5 \\
\hline EU Accession & 7,659 & 33.2 & 27.2 & 6.3 & 0.8 & 32.5 & 100 & 7.1 & 67.5 & 33.3 & 39.6 \\
\hline Hong Kong & 5,532 & 23.6 & 4.8 & 39.0 & 3.2 & 29.4 & 100 & 42.2 & 70.6 & 32.7 & 71.7 \\
\hline \multicolumn{12}{|l|}{ Wearing Apparel } \\
\hline China normal & 32,985 & 87.8 & 0.0 & 0.0 & 0.0 & 12.1 & 100 & 0.0 & 87.9 & 12.1 & 12.1 \\
\hline Western EU & 17,338 & 84.5 & 3.5 & 2.3 & 0.9 & 8.8 & 100 & 3.2 & 91.2 & 9.7 & 12.0 \\
\hline China processing & 14,144 & 43.5 & 0.9 & 1.0 & 0.0 & 54.6 & 100 & 1.0 & 45.4 & 54.6 & 55.6 \\
\hline EU Accession & 10,811 & 67.9 & 0.9 & 0.2 & 0.0 & 30.9 & 100 & 0.3 & 69.1 & 31.0 & 31.2 \\
\hline \multicolumn{12}{|l|}{ Leather Products } \\
\hline China normal & 16,370 & 87.8 & 1.1 & 1.2 & 0.0 & 10.0 & 100 & 1.2 & 90.1 & 10.0 & 11.1 \\
\hline China processing & 15,920 & 60.5 & 2.1 & 2.2 & 0.0 & 35.2 & 100 & 2.2 & 64.8 & 35.2 & 37.4 \\
\hline Western EU & 15,446 & 57.4 & 17.3 & 8.1 & 6.9 & 10.3 & 100 & 15.0 & 89.7 & 17.2 & 25.3 \\
\hline Vietnam & 5,398 & 48.3 & 1.0 & 0.3 & 0.0 & 50.3 & 100 & 0.3 & 49.7 & 50.3 & 50.6 \\
\hline EU Accession & 4,078 & 63.4 & 6.3 & 1.7 & 0.2 & 28.5 & 100 & 1.8 & 71.5 & 28.7 & 30.3 \\
\hline Brazil & 3,553 & 44.5 & 26.1 & 15.5 & 0.1 & 13.8 & 100 & 15.5 & 86.2 & 13.9 & 29.4 \\
\hline USA & 2,621 & 29.7 & 16.6 & 9.7 & 30.9 & 13.1 & 100 & 40.6 & 86.9 & 44.0 & 53.7 \\
\hline India & 2,491 & 60.2 & 13.8 & 9.7 & 0.1 & 16.3 & 100 & 9.7 & 83.7 & 16.4 & 26.0 \\
\hline Indonesia & 2,185 & 74.8 & 4.9 & 4.2 & 0.1 & 16.1 & 100 & 4.3 & 83.9 & 16.2 & 20.4 \\
\hline Thailand & 1,780 & 49.4 & 4.6 & 11.9 & 0.1 & 34.1 & 100 & 12.0 & 65.9 & 34.2 & 46.1 \\
\hline
\end{tabular}




\section{Table A5 Decomposition of gross exports, selected sectors for the 10 largest exporters, 2004- Continued}

\begin{tabular}{|c|c|c|c|c|c|c|c|c|c|c|c|}
\hline \multirow[b]{2}{*}{$\begin{array}{l}\text { Sector and } \\
\text { exporter }\end{array}$} & \multirow[b]{2}{*}{$\begin{array}{l}\text { Gross } \\
\text { exports }\end{array}$} & \multicolumn{6}{|c|}{ Basic decomposition } & \multicolumn{4}{|c|}{ Connection with existing measures } \\
\hline & & $\begin{array}{l}\text { DVA } \\
\text { in } \\
\text { direct } \\
\text { final } \\
\text { goods }\end{array}$ & $\begin{array}{c}\text { DVA in } \\
\text { interme- } \\
\text { diates } \\
\text { absorbed by } \\
\text { direct } \\
\text { importer } \\
\end{array}$ & $\begin{array}{c}\text { Indirect } \\
\text { DVA } \\
\text { exports } \\
\text { to third } \\
\text { countries }\end{array}$ & $\begin{array}{l}\text { Reflected } \\
\text { DVA }\end{array}$ & $\begin{array}{l}\text { Foreign } \\
\text { VA }\end{array}$ & Total & $\begin{array}{l}\text { Share } \\
\text { of VS1 }\end{array}$ & $\begin{array}{c}\text { Domestic } \\
\text { content }\end{array}$ & $\begin{array}{l}\text { Multiple } \\
\text { counting }\end{array}$ & $\begin{array}{l}\text { GVC } \\
\text { partici- } \\
\text { pation } \\
\text { (vertical } \\
\text { trade) }\end{array}$ \\
\hline & & $(1)$ & $(2)^{a}$ & $(3)^{\mathrm{a}}$ & $(4)^{\mathrm{a}}$ & (5) & (6) & (8) & (9) & $(10)$ & (11) \\
\hline Canada & 21,802 & 12.9 & 62.3 & 3.8 & 1.1 & 19.9 & 100 & 4.9 & 80.1 & 21.0 & 24.8 \\
\hline Western EU & 21,083 & 27.1 & 46.5 & 8.0 & 7.0 & 11.5 & 100 & 14.9 & 88.5 & 18.5 & 26.5 \\
\hline EU Accession & 15,072 & 32.3 & 37.8 & 6.0 & 0.5 & 23.4 & 100 & 6.5 & 76.6 & 23.9 & 29.9 \\
\hline China normal & 11,936 & 43.3 & 39.1 & 8.8 & 0.3 & 8.4 & 100 & 9.1 & 91.6 & 8.7 & 17.5 \\
\hline Malaysia & 5,529 & 17.3 & 44.7 & 13.3 & 0.1 & 24.6 & 100 & 13.4 & 75.4 & 24.7 & 38.0 \\
\hline Brazil & 4,084 & 16.4 & 66.0 & 9.4 & 0.1 & 8.0 & 100 & 9.5 & 92.0 & 8.1 & 17.5 \\
\hline Mexico processing & 3,549 & 52.1 & 8.2 & 1.0 & 0.0 & 38.7 & 100 & 1.0 & 61.3 & 38.7 & 39.7 \\
\hline \multicolumn{12}{|c|}{ Paper Products \& Publishing } \\
\hline Western EU & 34,830 & 18.0 & 53.5 & 12.3 & 8.5 & 7.7 & 100 & 20.8 & 92.3 & 16.2 & 28.5 \\
\hline USA & 22,573 & 18.7 & 48.5 & 10.9 & 13.5 & 8.4 & 100 & 24.4 & 91.7 & 21.9 & 32.8 \\
\hline Canada & 19,186 & 7.1 & 63.0 & 10.0 & 1.1 & 18.8 & 100 & 11.1 & 81.2 & 19.9 & 29.9 \\
\hline EU Accession & 5,529 & 20.0 & 45.7 & 8.9 & 0.8 & 24.7 & 100 & 9.7 & 75.4 & 25.4 & 34.3 \\
\hline \multicolumn{12}{|c|}{ Petroleum \& Coal Production } \\
\hline Western EU & 21,150 & 0.0 & 31.3 & 7.0 & 4.3 & 57.4 & 100 & 11.3 & 42.6 & 61.7 & 68.7 \\
\hline USA & 16,761 & 0.0 & 33.7 & 8.6 & 5.0 & 52.7 & 100 & 13.6 & 47.4 & 57.6 & 66.3 \\
\hline Russia & 12,619 & 0.0 & 70.3 & 22.1 & 0.5 & 7.0 & 100 & 22.7 & 93.0 & 7.6 & 29.7 \\
\hline Singapore & 9,172 & 0.0 & -0.1 & -0.1 & 0.0 & 100.2 & 100 & -0.1 & -0.2 & 100.2 & 100.1 \\
\hline China normal & 6,458 & 0.0 & 48.3 & 16.8 & 1.1 & 33.8 & 100 & 17.9 & 66.2 & 34.9 & 51.7 \\
\hline Korea & 6,336 & 0.0 & 31.9 & 12.8 & 0.6 & 54.8 & 100 & 13.3 & 45.2 & 55.3 & 68.1 \\
\hline Canada & 5,165 & 0.0 & 57.0 & 10.2 & 1.4 & 31.4 & 100 & 11.6 & 68.6 & 32.8 & 43.0 \\
\hline EU Accession & 3,962 & 0.0 & 38.8 & 11.4 & 0.6 & 49.2 & 100 & 12.0 & 50.8 & 49.8 & 61.2 \\
\hline India & 3,573 & 0.0 & 28.9 & 11.4 & 0.3 & 59.4 & 100 & 11.7 & 40.6 & 59.7 & 71.2 \\
\hline EFTA & 3,034 & 0.0 & 62.6 & 13.8 & 0.8 & 22.9 & 100 & 14.5 & 77.1 & 23.7 & 37.4 \\
\hline
\end{tabular}




\section{Table A5 Decomposition of gross exports, selected sectors for the 10 largest exporters, 2004- Continued}

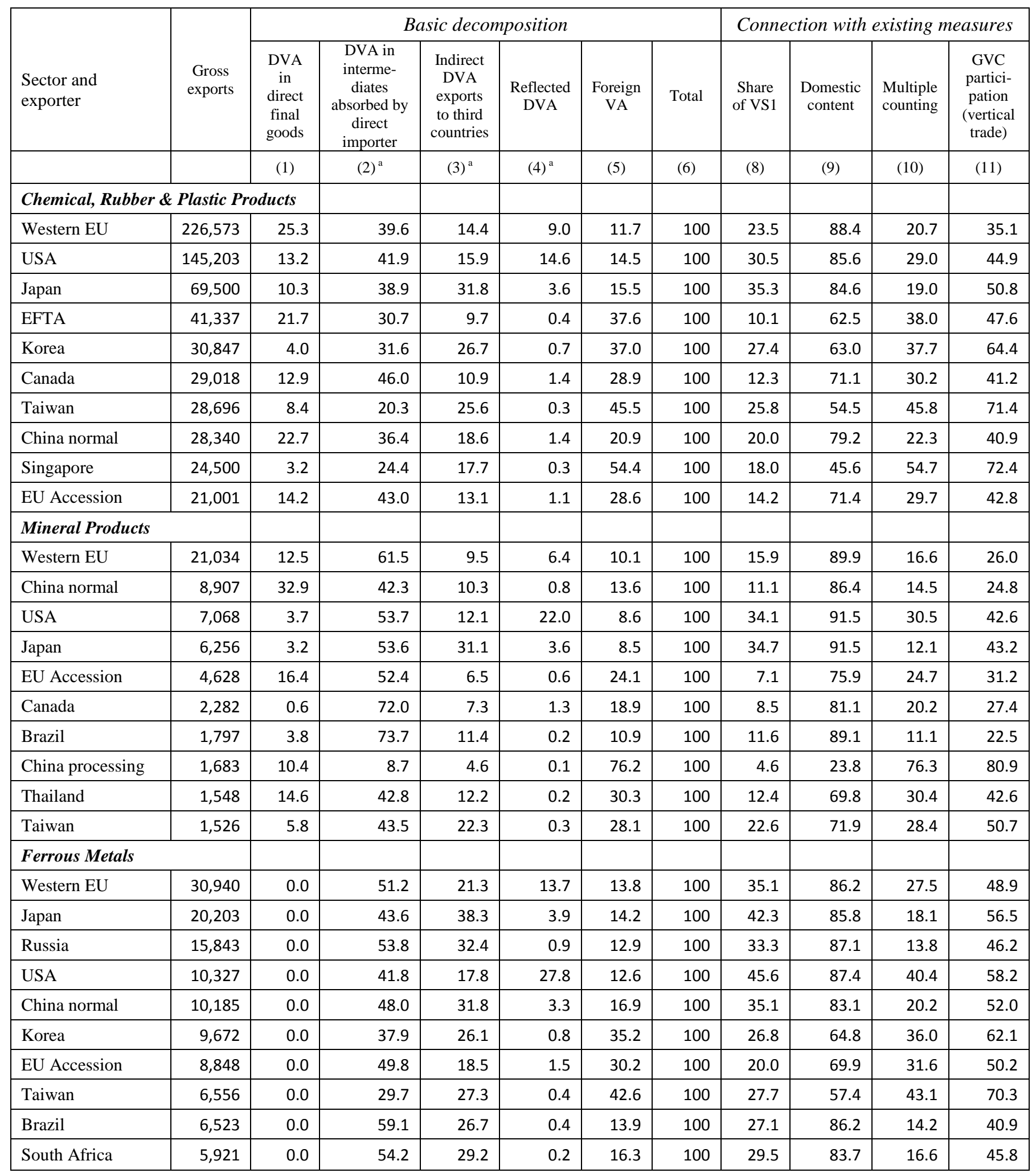




\section{Table A5 Decomposition of gross exports, selected sectors for the 10 largest exporters, 2004- Continued}

\begin{tabular}{|c|c|c|c|c|c|c|c|c|c|c|c|}
\hline \multirow[b]{2}{*}{$\begin{array}{l}\text { Sector and } \\
\text { exporter }\end{array}$} & \multirow[b]{2}{*}{$\begin{array}{l}\text { Gross } \\
\text { exports }\end{array}$} & \multicolumn{6}{|c|}{ Basic decomposition } & \multicolumn{4}{|c|}{ Connection with existing measures } \\
\hline & & $\begin{array}{l}\text { DVA } \\
\text { in } \\
\text { direct } \\
\text { final } \\
\text { goods }\end{array}$ & $\begin{array}{c}\text { DVA in } \\
\text { interme- } \\
\text { diates } \\
\text { absorbed by } \\
\text { direct } \\
\text { importer } \\
\end{array}$ & $\begin{array}{c}\text { Indirect } \\
\text { DVA } \\
\text { exports } \\
\text { to third } \\
\text { countries }\end{array}$ & $\begin{array}{c}\text { Reflected } \\
\text { DVA }\end{array}$ & $\begin{array}{c}\text { Foreign } \\
\text { VA }\end{array}$ & Total & $\begin{array}{l}\text { Share } \\
\text { of VS1 }\end{array}$ & $\begin{array}{c}\text { Domestic } \\
\text { content }\end{array}$ & $\begin{array}{l}\text { Multiple } \\
\text { counting }\end{array}$ & $\begin{array}{l}\text { GVC } \\
\text { partici- } \\
\text { pation } \\
\text { (vertical } \\
\text { trade) }\end{array}$ \\
\hline & & $(1)$ & $(2)^{\mathrm{a}}$ & $(3)^{\mathrm{a}}$ & $(4)^{\mathrm{a}}$ & (5) & (6) & (8) & (9) & $(10)$ & $(11)$ \\
\hline Western EU & 20,457 & 1.4 & 41.6 & 25.4 & 15.3 & 16.3 & 100 & 40.7 & 83.7 & 31.6 & 57.0 \\
\hline EFTA & 19,549 & 0.0 & 36.6 & 17.8 & 0.6 & 45.1 & 100 & 18.3 & 54.9 & 45.7 & 63.4 \\
\hline Canada & 16,990 & 0.0 & 47.2 & 18.3 & 1.9 & 32.6 & 100 & 20.2 & 67.4 & 34.5 & 52.8 \\
\hline USA & 16,283 & 0.3 & 32.7 & 27.7 & 21.7 & 17.7 & 100 & 49.3 & 82.3 & 39.4 & 67.0 \\
\hline Japan & 8,612 & 0.0 & 25.4 & 42.5 & 4.9 & 27.1 & 100 & 47.4 & 72.9 & 32.0 & 74.6 \\
\hline Korea & 5,553 & 0.0 & 15.0 & 23.9 & 0.9 & 60.2 & 100 & 24.8 & 39.8 & 61.1 & 85.0 \\
\hline China normal & 5,501 & 1.5 & 40.8 & 34.7 & 3.0 & 20.0 & 100 & 37.7 & 80.0 & 23.0 & 57.7 \\
\hline \multicolumn{12}{|c|}{ Transportation Equipment } \\
\hline USA & 63,850 & 41.8 & 28.4 & 10.7 & 4.9 & 14.2 & 100 & 15.6 & 85.8 & 19.1 & 29.8 \\
\hline Western EU & 50,704 & 54.6 & 19.2 & 7.8 & 4.2 & 14.3 & 100 & 12.0 & 85.8 & 18.4 & 26.3 \\
\hline Japan & 16,881 & 60.3 & 17.0 & 7.0 & 0.6 & 15.2 & 100 & 7.5 & 84.8 & 15.8 & 22.7 \\
\hline Korea & 12,858 & 67.6 & 2.1 & 0.8 & 0.0 & 29.5 & 100 & 0.9 & 70.5 & 29.6 & 30.4 \\
\hline \multicolumn{12}{|c|}{ Machinery and Equipment } \\
\hline Western EU & 309,383 & 52.7 & 21.8 & 7.9 & 5.4 & 12.4 & 100 & 13.2 & 87.7 & 17.7 & 25.6 \\
\hline USA & 183,179 & 51.1 & 20.7 & 8.8 & 8.8 & 10.6 & 100 & 17.6 & 89.4 & 19.4 & 28.2 \\
\hline Japan & 162,999 & 52.2 & 19.6 & 15.0 & 1.7 & 11.6 & 100 & 16.7 & 88.5 & 13.2 & 28.2 \\
\hline China processing & 54,400 & 25.9 & 13.3 & 12.1 & 0.4 & 48.3 & 100 & 12.5 & 51.7 & 48.7 & 60.8 \\
\hline EFTA & 47,748 & 40.2 & 14.4 & 5.2 & 0.2 & 40.1 & 100 & 5.3 & 59.9 & 40.2 & 45.4 \\
\hline China normal & 44,087 & 39.0 & 30.4 & 14.3 & 1.2 & 15.1 & 100 & 15.5 & 84.9 & 16.3 & 30.6 \\
\hline Korea & 43,488 & 52.4 & 12.1 & 9.1 & 0.3 & 26.1 & 100 & 9.4 & 73.9 & 26.4 & 35.5 \\
\hline Taiwan & 42,724 & 39.6 & 10.7 & 9.1 & 0.2 & 40.5 & 100 & 9.2 & 59.5 & 40.6 & 49.7 \\
\hline EU Accession & 41,086 & 26.9 & 30.6 & 8.1 & 0.8 & 33.6 & 100 & 8.9 & 66.4 & 34.4 & 42.5 \\
\hline Mexico processing & 34,979 & 10.5 & 8.8 & 3.0 & 0.1 & 77.7 & 100 & 3.1 & 22.3 & 77.7 & 80.8 \\
\hline
\end{tabular}


Table A5 Decomposition of gross exports, selected sectors for the 10 largest exporters, 2004Continued

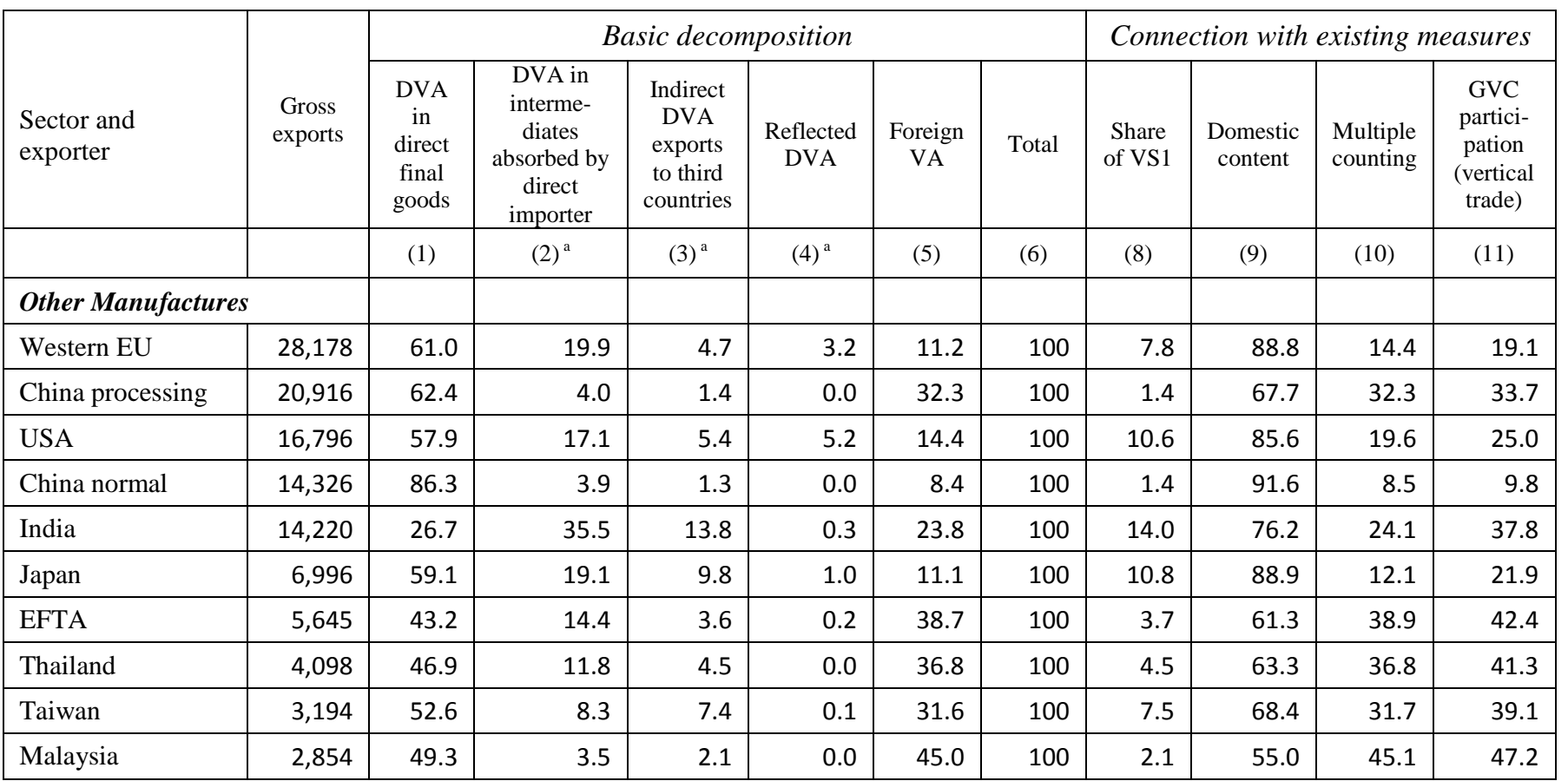

Note: Columns (1) through (11) are expressed as a share of total gross exports. Column numbering reflects table 2 in main text.

${ }^{\mathrm{a}}$ First order approximations

Table A6 Magnification of trade costs on final manufacturing goods exports from vertical specialization, 2004 -- Descriptive Statistics for detailed sector level results

\begin{tabular}{|c|c|c|c|c|c|c|c|c|c|c|c|c|c|}
\hline & \multicolumn{3}{|c|}{ Standard trade costs } & \multirow{3}{*}{$\begin{array}{l}\text { Foreign } \\
\text { content } \\
\text { share }\end{array}$} & \multicolumn{3}{|c|}{$\begin{array}{l}\text { Trade cost for imported } \\
\text { inputs }\end{array}$} & \multicolumn{3}{|c|}{ Magnification factor $^{\mathrm{a}}$} & \multirow{3}{*}{$\begin{array}{l}\text { Domestic } \\
\text { content } \\
\text { share }\end{array}$} & \multirow{3}{*}{$\begin{array}{c}\text { Effective } \\
\text { tariff rate } \\
(\mathbf{2})+(7) /(11)\end{array}$} & \multirow{3}{*}{$\begin{array}{l}\text { Magnifi- } \\
\text { cation } \\
\text { ratio } \\
\mathbf{( 1 2 ) / ( 2 )}\end{array}$} \\
\hline & Trans- & Tariff & Total & & Trans- & Tariff & Total & & Tariff & Total & & & \\
\hline & port & & $(1)+(2)$ & & port & & $(5)+(6)$ & port & & & & & \\
\hline & (1) & (2) & (3) & (5) & (6) & (7) & (8) & (9) & (10) & (1) & (11) & (12) & (13) \\
\hline $\mathbf{N}$ & 445 & 445 & 445 & 445 & 445 & 445 & 445 & 445 & 445 & 445 & 445 & 445 & 439 \\
\hline MIN & 0.0 & 0.0 & 0.0 & 3.0 & 0.1 & 0.0 & 0.2 & 0.0 & 0.0 & 0.0 & 9.2 & 0.0 & 1.1 \\
\hline MAX & 22.3 & 20.3 & 31.3 & 90.9 & 9.4 & 20.4 & 22.7 & 171.4 & 85.4 & 255.8 & 97.0 & 172.1 & 281.0 \\
\hline MEAN & 6.1 & 4.4 & 10.5 & 30.7 & 1.7 & 1.9 & 3.6 & 1.7 & 1.5 & 2.1 & 69.3 & 10.3 & 4.5 \\
\hline STD & 4.6 & 3.7 & 6.5 & 18.0 & 1.4 & 2.6 & 3.2 & 8.1 & 4.1 & 12.2 & 18.0 & 12.9 & 19.5 \\
\hline
\end{tabular}




\section{Reference}

Baldwin, Richard, 2008, "Managing the Noodle Bowl: The Fragility of East Asian Regionalism”, The Singapore Economic Review 53(3):449-478.

Dean, Judith, Mary Lovely, and Jesse Mora. 2009. "Decomposing China-Japan-U.S. trade: Vertical specialization, ownership, and organizational form.” Journal of Asian Economics 20(6): 596-610.

Koopman, Robert, Zhi Wang, and Shang-Jin Wei. 2008. "How Much Chinese Exports Is Really Made in China-Assessing Foreign and Domestic Value-added in Gross Exports.” NBER Working Paper 14109.

Koopman, Robert, Zhi Wang and Shang-Jin Wei. 2011. "How Much of China’s Exports is Really Made in China? Computing Domestic Content in Exports When Processing Trade is Pervasive." Paper presented at workshop "The Fragmentation of Global Production and Trade in Value-Added - Developing New Measures of Cross Border Trade, World Bank, Washington DC, June.

Maurer, Andreas and Christophe Degain. 2010. "Globalization and Trade Flows: What you see is not what you get!" Staff Working Paper ERSD-2010-12, World Trade Organization.

Nag, Biswajit, Saikat Banerjee, and RittwikChatterjee. 2007. "Changing Features of the Automobile Industry in Asia.” Working Paper Series No. 37, Asia-Pacific Research and Training Network on Trade. 